\title{
Deir el-Médina (2020)
}

Mission d'étude et de restauration

Cédric Larcher, Julian Posch, Dominique Lefevre, Manon Lefevre, Marine Yoyotte, Elisa Fiore Marochetti, Gersande Eschenbrenner Diemer, Anna Giulia de Marco, Lisa Sartini, Margaret Serpico, Ben J.J. Haring, Kyra van der Moezel, Marie-Lys Arnette, Cédric Gobeil, Anne Austin, Sandrine Vuilleumier, Didier Devauchelle, Ghislaine Widmer et Christian Dupuis

\section{(2) OpenEdition}

Édition électronique

URL : https://journals.openedition.org/baefe/2985

DOI : $10.4000 /$ baefe.2985

ISSN : 2732-687X

Éditeur

ResEFE

\section{Référence électronique}

Cédric Larcher, Julian Posch, Dominique Lefevre, Manon Lefevre, Marine Yoyotte, Elisa Fiore Marochetti, Gersande Eschenbrenner Diemer, Anna Giulia de Marco, Lisa Sartini, Margaret Serpico, Ben J.J. Haring, Kyra van der Moezel, Marie-Lys Arnette, Cédric Gobeil, Anne Austin, Sandrine Vuilleumier, Didier Devauchelle, Ghislaine Widmer et Christian Dupuis, « Deir el-Médina (2020)» [notice archéologique], Bulletin archéologique des Écoles françaises à l'étranger [En ligne], Égypte, mis en ligne le 30 mai 2021, consulté le 27 juillet 2021. URL : http://journals.openedition.org/baefe/2985 ; DOI : https://doi.org/10.4000/baefe.2985

Ce document a été généré automatiquement le 27 juillet 2021

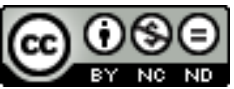

Le Bulletin archéologique des Écoles françaises à l'étranger est mise à disposition selon les termes de la Licence Creative Commons Attribution - Pas d'Utilisation Commerciale - Pas de Modification 4.0 International. 


\title{
Deir el-Médina (2020)
}

Mission d'étude et de restauration

\author{
Cédric Larcher, Julian Posch, Dominique Lefevre, Manon Lefevre, Marine \\ Yoyotte, Elisa Fiore Marochetti, Gersande Eschenbrenner Diemer, \\ Anna Giulia de Marco, Lisa Sartini, Margaret Serpico, Ben J.J. Haring, \\ Kyra van der Moezel, Marie-Lys Arnette, Cédric Gobeil, Anne Austin, \\ Sandrine Vuilleumier, Didier Devauchelle, Ghislaine Widmer et Christian \\ Dupuis
}

\section{NOTE DE L'AUTEUR}

Année de la campagne : 2020 (5 janvier - 1 mars)

Autorité nationale présente : Le ministère du Tourisme et des Antiquités (MoTA) était représenté par Mahmud Moussa, directeur de la zone sud de la rive ouest de Louqsor, Ahmed Nazeer Askr, inspecteur en chef de la rive ouest de Louqsor et Mahassen Abd Alhamed, Taha Hessein, Saleh Mohamed Ahmed et Mahmoud Saad Eid Yousif, inspecteurs, et les restaurateurs Ahmed Ali Hussein Dhawi et Mohamed Salah Numéro et intitulé de l'opération de terrain : 17148 - Deir el-Médina, mission d'étude et de restauration du mobilier et des monuments

Composition de l'équipe de terrain : L'équipe de terrain était composée de Cédric Larcher (égyptologue, Ifao), Marie-Lys Arnette (égyptologue, Universität Freiburg), Anne Austin (anthropologue, University of Missouri-St. Louis), Elizabeth Bettles (égyptologue, Universiteit Leiden), Chiara Bianchi (restauratrice-conservatrice, ENSAV La Cambre), Audrey Crabbé (égyptologue, Universiteit Leiden), Rosalie David (égyptologue, University of Manchester), Paolo Del Vesco (égyptologue, Museo Egizio, Turin), Nicolas Dell'Aquila, (photographe, Politecnico di Milano), Didier Devauchelle (égyptologue, université de Lille), Gersande Eschenbrenner Diemer (égyptologue, Universidad de Jaén), Christian Dupuis (géologue, université de Mons), Hassan El-Amir (restaurateur-conservateur, Ifao), Omaïma El-Shal (égyptologue, Université Misr for Science and Technology), Mazen Essam (assistant, Ifao), Annie Gasse (égyptologue, CNRS), Cédric Gobeil (égyptologue, Museo Egizio, Turin), Christian Gréco (égyptologue, 
Museo Egizio, Turin), Ben J.J. Haring (égyptologue, Universiteit Leiden), Dominique Lefevre (égyptologue, université de Genève), Manon Lefevre (restauratriceconservatrice, indépendante), Louise Loiseau (restauratrice-conservatrice, ENSAV La Cambre), Alicia Lozano Lopez (restauratrice-conservatrice, ENSAV La Cambre), Mélie Louys (égyptologue-anthropologue, École du Louvre), Ihab Ibrahim Mohamed (photographe, Ifao), Anna Giulia de Marco (égyptologue, Università di Pisa), Paolo Marini (égyptologue, Museo Egizio, Turin), Elisa Fiore Marochetti (égyptologue, Soprintendenza Archeologia Belle Arti e Paesaggio di Torino), Huzeifa Magdy Ahmed (égyptologue, Université Misr for Science and Technology), Alessandro Mandelli (topographe, Politecnico di Milano), Federico Poole (égyptologue, Museo Egizio, Turin), Julian Posch (égyptologue, Universität Wien), Marianne Rochebeuf (restauratriceconservatrice, indépendante), Corina Rossi (égyptologue, Politecnico di Milano), Lisa Sartini (égyptologue, Université de Pise), Kyra van der Moezel (égyptologue, Johannes Gutenberg-Universität Mainz), Margaret Serpico (égyptologue, University College de Londres), Isabelle Vranckx (restauratrice-conservatrice, ENSAV La Cambre), Sandrine Vuilleumier (égyptologue, université de Lausanne), Keith White (anthropologue, University of Manchester), Ghislaine Widmer (égyptologue, université de Lille), Mohamed Younes (restaurateur-conservateur, Ifao), Marine Yoyotte (égyptologue, Ifao), Mohamed Youssef Sedek (restaurateur-conservateur, Université Misr for Science and Technology).

Partenariats institutionnels : La mission bénéficie du soutien de Universiteit Leiden, University of Manchester, University of Missouri-St. Louis, Universidad de Jaén, université de Genève, Université Misr for Science and Technology, Università di Pisa, Universität Wien, université de Lille, université de Lausanne, University College London, Museo Egizio (Turin), Politecnico di Milano, Soprintendenza Archeologia Belle Arti e Paesaggio de Turin, et ERC Locus Ludi ADG n ${ }^{\circ} 751520$, Universität Freiburg.

Organismes financeurs :

- Fonds Khéops pour l'archéologie

- Fondation Gandur pour l'art

1 La campagne 2020 de la mission Ifao à Deir el-Médina s'est déroulée du 5 janvier au $1^{\text {er }}$ mars sous la direction de Cédric Larcher. Nous remercions le Prof. Dr Khaled elEnany, ministre du Tourisme et des Antiquités, le Dr Mostafa Waziri, secrétaire général du Conseil suprême des antiquités, le Dr Nashwa Gaber, directrice des missions étrangères et des commissions permanentes, le Dr Mohamed Yahya, directeur général des Antiquités de Haute Égypte, M. Fathy Yasin Abd el-Karim, directeur général de la rive ouest de Louqsor, M. Ramadan Ahmed Ali Ahmed, directeur général des missions étrangères de la rive ouest de Louqsor, $\mathrm{M}$. Mahmud Moussa, directeur de la zone sud de la rive ouest de Louqsor, M. Ahmed Nazeer Askr, inspecteur en chef de la rive ouest de Louqsor et Mme Mahassen Abd Alhamed, M. Taha Hessein, M. Saleh Mohamed Ahmed et M. Mahmoud Saad Eid Yousif, inspecteurs, et les restaurateurs M. Ahmed Ali Hussein Dhawi et M. Mohamed Salah.

2 Le programme approuvé par la Comité permanent comprenait l'étude et la restauration des tombes TT 4, TT 214, TT 216 et TT 298, l'étude du matériel et des restes humains entreposés dans la TT 298, l'étude des objets conservés dans les magasins 23 et 25 et l'étude du programme décoratif du temple d'Hathor. Parallèlement, l'analyse géoarchéologique du site a été poursuivie. À la demande du Comité Permanent, la restauration de la chapelle de la TT 340 a été assurée par la mission. 


\section{Restauration et étude des tombes de la nécropole de l'ouest}

\subsection{TT 4 - Tombe de Qen}

3 Positionnée au sud de la TT 335 (Nakhtamon) et au nord de la TT 213 (Penamon), la tombe du Qen a un plan relativement simple. Sa superstructure est composée d'une cour menant à une chapelle au décor à la fois sculpté et peint, fait rare pour les tombes de l'époque de Deir el-Médina. La chapelle est de dimensions modestes : 3,27 m nordsud sur 2,03 m est-ouest. Un puits dans la partie nord-ouest de la chapelle de 2,40 m de profondeur donne accès à deux chambres funéraires non décorées (caveau 1 et caveau 2). La première mesure $3,70 \mathrm{~m}$ sur $3,20 \mathrm{~m}$ et la seconde 3,80 sur $2 \mathrm{~m}$. Un puits extérieur ( $\left.\mathrm{n}^{\circ} 1054\right)$, situé au sud de la chapelle, permet l'accès à un troisième caveau $(3,80 \mathrm{~m}$ sur $3,50 \mathrm{~m})$, qui communique avec le caveau 2 et qui pourrait être un caveau plus ancien réutilisé par Qen. À la suite d'un incendie, seuls un pilier et le montant sud de la porte portent encore des traces d'inscriptions. Le mur nord conserve des traces de décorations.

La littérature se rapportant à la tombe évoque principalement les textes inscrits sur les parois de la chapelle. Seules deux photographies des reliefs de la TT 4 ont été à ce jour publiées, montrant l'importance d'une publication globale de cette sépulture ${ }^{1}$.

Depuis 2013, plusieurs volets de l'étude du tombeau ont été menés : réalisation de facsimilés, établissement du relevé topographique et d'une maquette 3D par Olivier Onézime (topographe), couverture photographique du tombeau par Ihab Mohamed Ibrahim (photographe, Ifao) et étude des objets conservés dans les magasins Carter.

En 2019, un test laser a été effectué par une équipe de restaurateurs (Christina Verbeek et Stefan Lochner) dans la chambre funéraire décorée (caveau 3) afin de déterminer de quelle manière ôter l'épaisse couche de suie sous laquelle des décors sont partiellement visibles. Outre la suie, une couche d'argile combinée avec une couche de saleté relativement épaisse s'est déposée, ce qui demanderait un long processus de restauration pour être nettoyée. L'étude de la TT 4 se poursuit donc à ce stade en l'état. De nouvelles recherches ont été effectuées en 2019 pour rassembler tous les monuments provenant de la TT 4 et un premier séjour au Griffith Institute d'Oxford a permis de consulter partiellement les archives de Jacques Jean Clère qui y sont conservées.

7 Au cours des deux semaines passées à Deir el-Médina pendant la mission de 2020, les dessins réalisés entre 2014 et 2016 ont pu être vérifiés et comparés avec les archives photographiques anciennes. Il a été possible également d'encoder les textes hiéroglyphiques des murs nord, sud et ouest de la chapelle, qui sont les moins lisibles, et de procéder à leur translittération. En raison de la situation sanitaire actuelle, il n'a pas encore été possible d'achever la mission muséographique afin de réunir l'ensemble des objets provenant de la TT 4. Celle-ci sera effectuée le plus rapidement possible afin de pouvoir entamer la rédaction de la publication. 


\subsection{TT 214 - Tombe de Khaouy}

Du 21 janvier au 6 février 2020, des membres du Museo Egizio de Turin et de l'École Polytechnique de Milan ont travaillé ensemble sur un projet d'étude et de conservation de la tombe TT 214 du gardien Khaouy à Deir el-Médina, suivant une convention signée avec l'Ifao qui supervise l'ensemble du projet. L'équipe était composée de Cédric Gobeil, Paolo Del Vesco, Federico Poole, Nicola Dell'Aquila et Alessandro Mandelli. Pendant quelques jours, l'équipe a eu le plaisir d'accueillir Christian Greco et Corinna Rossi pour une mission de conseil.

Dans son Rapport de 1927, Bernard Bruyère (070406510) indique que la montagne naturelle au-dessus du plafond de la deuxième chambre funéraire de la TT 214 s'est effondrée la même année, interdisant l'accès à la troisième et dernière chambre funéraire, la seule qui soit décorée. Depuis lors, cette salle n'avait été atteinte qu'une seule fois, en 2014 par la mission de l'Ifao à des fins de documentation (relevé photographique). Il était donc prioritaire, cette saison, d'enlever définitivement l'épaisse couche de roches effondrées qui bloquait l'entrée de la chambre funéraire décorée pour en faire l'étude et dresser un premier bilan de son état de conservation. Une porte métallique à double vantaux a été installée (fig. 1) pour assurer sa protection et en faciliter l'accès lors des prochaines saisons.

Fig. 1. Porte métallique installée à l'entrée de la troisième chambre funéraire (C. Gobeil).

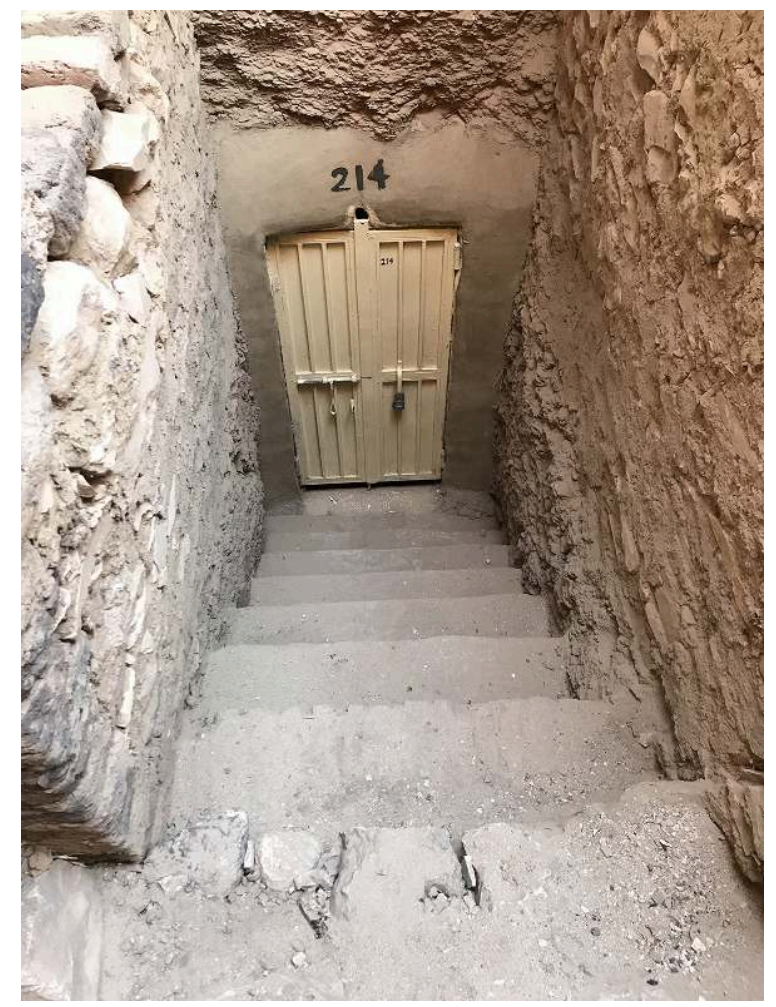

(c) Ifao. 17148_2020_NDMPF_001

Les premiers efforts engagés furent de nettoyer le sol de l'avant-cour, le puits vertical et les deux premières chambres funéraires (fig. 2). Le sol à l'intérieur de la chapelle a aussi été nettoyé. À l'exception de l'avant-cour, toutes les structures étaient presque complètement remplies par des décennies de débris et d'ordures poussés par le vent. 
Notre nettoyage a montré que la surface de l'avant-cour était en fait formée par un nivellement artificiel mis en place par B. Bruyère pour retenir les terres devant la chapelle. La partie supérieure de cette couche, d'environ $20 \mathrm{~cm}$ d'épaisseur, contenait une quantité de bandelettes de lin, de restes humains (ossements et fragments momifiés) et de fragments de mobiliers funéraires (surtout des morceaux de cercueils en bois et des ouchebtis). Il semble probable que Bruyère a utilisé une grande quantité de débris produits par la fouille du secteur et d'artefacts qui étaient pour lui sans intérêt pour créer cet horizon artificiel. Tous les objets découverts durant notre campagne ont été numérotés, inventoriés et photographiés.

Fig. 2. Première chambre funéraire après nettoyage du sol (C. Gobeil).

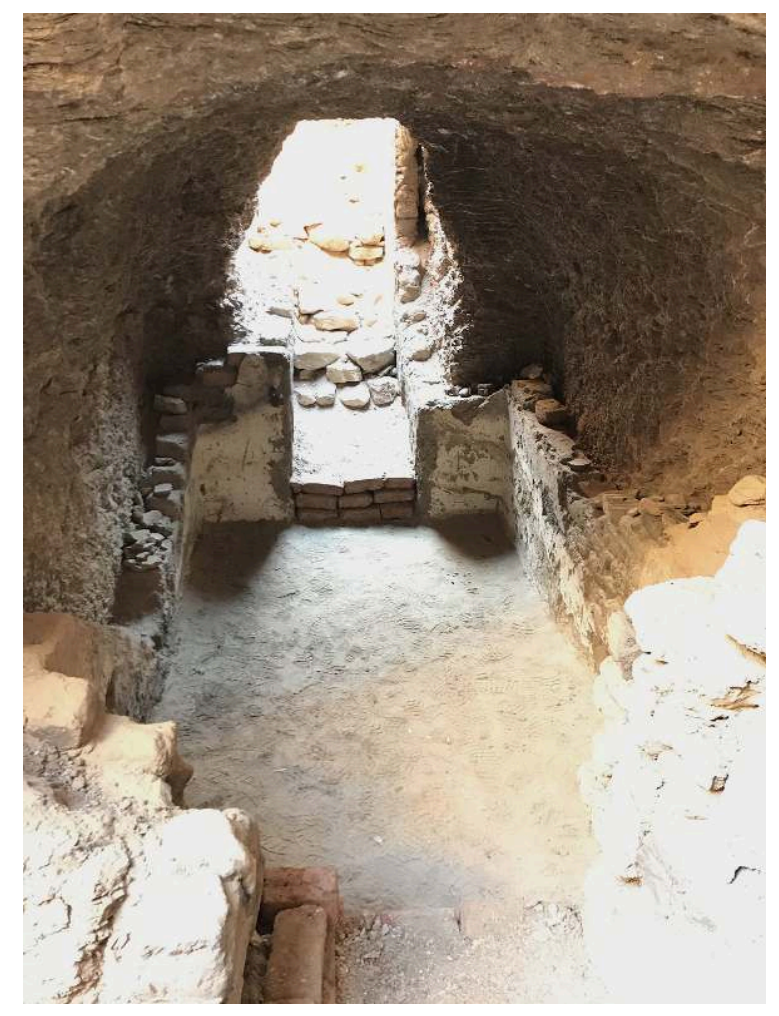

(C) Ifao. 17148_2020_NDMPF_002

11 Cette saison, à l'ouverture de la chapelle de la TT 214, seize fragments de relief en calcaire, dont sept qui appartiennent à l'embrasure droite de l'entrée de la chapelle, ont été trouvés. Leur identification a été permise grâce à une reconstitution du décor de la chapelle proposée par B. Bruyère dans son Rapport de 1927. Certains de ces fragments pourraient, au contraire, ne pas provenir de la tombe. Tous ont été dessinés et photographiés afin d'être étudiés plus en détail.

12 Le nettoyage du puits vertical et des deux premières chambres funéraires n'a révélé aucun artefact d'un intérêt particulier, mais a permis à l'ingénieur de la mission de réaliser le modèle, le plan (fig. 3) et la section de l'ensemble complet de la TT 214. Toutes ces parties de la tombe feront l'objet d'une conservation adaptée au cours des prochaines saisons.

13 Le photographe de la mission a réalisé un relevé photographique complet de la dernière chambre funéraire et de l'intérieur de la chapelle. Ces relevés nous 
permettront d'évaluer les travaux de conservation à mener et de faire une étude approfondie de la décoration.

Fig. 3. Plan de la TT 214 (A. Mandelli).

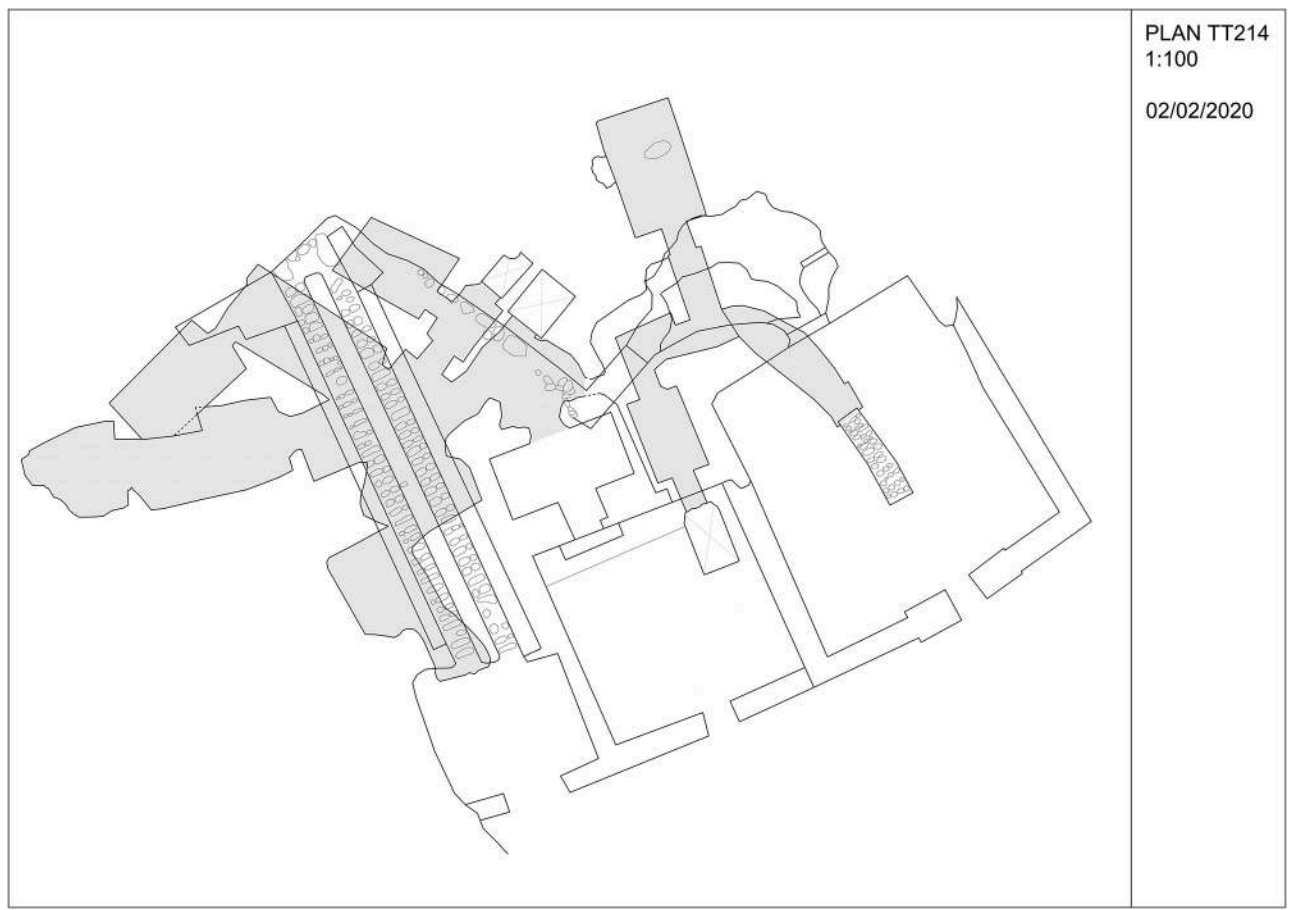

C Ifao. 17148_2020_NDMDM_001

\subsection{TT 216 - Tombe de Néferhotep}

La mission 2020 s'est déroulée 10 janvier au 26 février 2020. L'équipe était composée de Dominique Lefevre, Cédric Larcher, Manon Lefevre, Isabelle Vrancks, Marianne Rochebeuf, Alicia Lozano Lopez, Chiara Bianchi et Louise Loiseau. Une dizaine de jours de préparation au début du mois de janvier a permis d'améliorer les conditions d'intervention dans la tombe. Après nettoyage du sol du couloir, un parquet a été installé dans cette partie de la chapelle, facilitant grandement tant les observations que les opérations de restauration. D'autres éléments mobiliers en bois - des rampes essentiellement - ont été fabriqués et mis en place afin de préserver les passages constitués de dalles en pierre, certaines fragilisées par le passage continu des intervenants sur le chantier.

Les opérations de restauration ont concerné les peintures de la chapelle (et les enduits de préparation sous-jacents) et les enduits extérieurs. De son côté, l'équipe «sculpture » a multiplié les interventions. À côté de celle qui était programmée sur le bas-relief sud de l'entrée, elle a procédé au constat d'état du relief en forme de porteenseigne dit «de Pached », d'un socle, d'un élément désigné par B. Bruyère comme un chapiteau de colonne, mais qui est plus probablement la partie supérieure d'un montant de porte, et de structures présentes dans la seconde cour. Le rapport d'intervention complet, accompagné de photographies, a été déposé au service des archives et collections. 


\subsubsection{Restauration des peintures}

La restauration des peintures a concerné les parois est section sud, paroi sud de la salle transversale et de deux montants de l'entrée du couloir.

\subsubsection{Parois est section sud et sud de la première salle}

17 Les parois est section sud et sud sont très lacunaires et ne présentent que quelques restes de polychromie nécessitant un traitement de consolidation et d'adhésion. À certains endroits, la matière est pulvérulente et les couches manquent d'adhésion entre elles. Des éclaboussures de plâtre, des résidus de suie très localisés, d'excréments aviaires et de nids de guêpes maçonnes posent des problèmes de lisibilité des scènes. Un premier nettoyage à sec de la couche picturale a été effectué par différents moyens : dépoussiérage à la poire et au pinceau, dépoussiérage et abrasion superficielle de la couche de badigeon ocre non originale, dégrossissement mécanique des coulées de plâtre et des nids de guêpes maçonnes, retrait de l'amas d'enduit au marteau et burin. Puis un second nettoyage, chimique, a consisté en trois actions ciblées : élimination des restes de coulées de plâtre et des nids de guêpes maçonnes, élimination de la couche de badigeon ocre, retrait des amas d'enduit anciens par humidification. Les cavités profondes de la paroi qui se trouvaient au milieu des restes du décor polychrome, et en perturbaient la lisibilité, ont été bouchées.

\subsubsection{Les montants intérieurs}

Deux montants encadrant l'entrée du couloir font trois mètres de haut (le sommet n'est pas conservé) et $39 \mathrm{~cm}$ de large. Ce sont les seuls endroits de la tombe où une partie du décor a été gravée avant application de la polychromie. La partie basse montre le défunt et son épouse assis sur un tabouret, regardant vers l'entrée du couloir (fig. 4). Cette scène figurée est surmontée d'une inscription funéraire verticale gravée sur deux colonnes, au bénéfice du propriétaire de la tombe. La première intervention a concerné la suppression des fientes aviaires, préalable indispensable à l'accès à l'ensemble de la stratigraphie. L'enlèvement des nids de guêpes maçonnes s'est effectué avec la même technique. Le retrait de ces éléments extérieurs a permis de voir la fragilité de certaines zones de la stratigraphie composant ce décor. 
Fig. 4a-b. Montant sud entre la salle oblongue et la salle longitudinale, avant et après restauration (M. Lefevre).
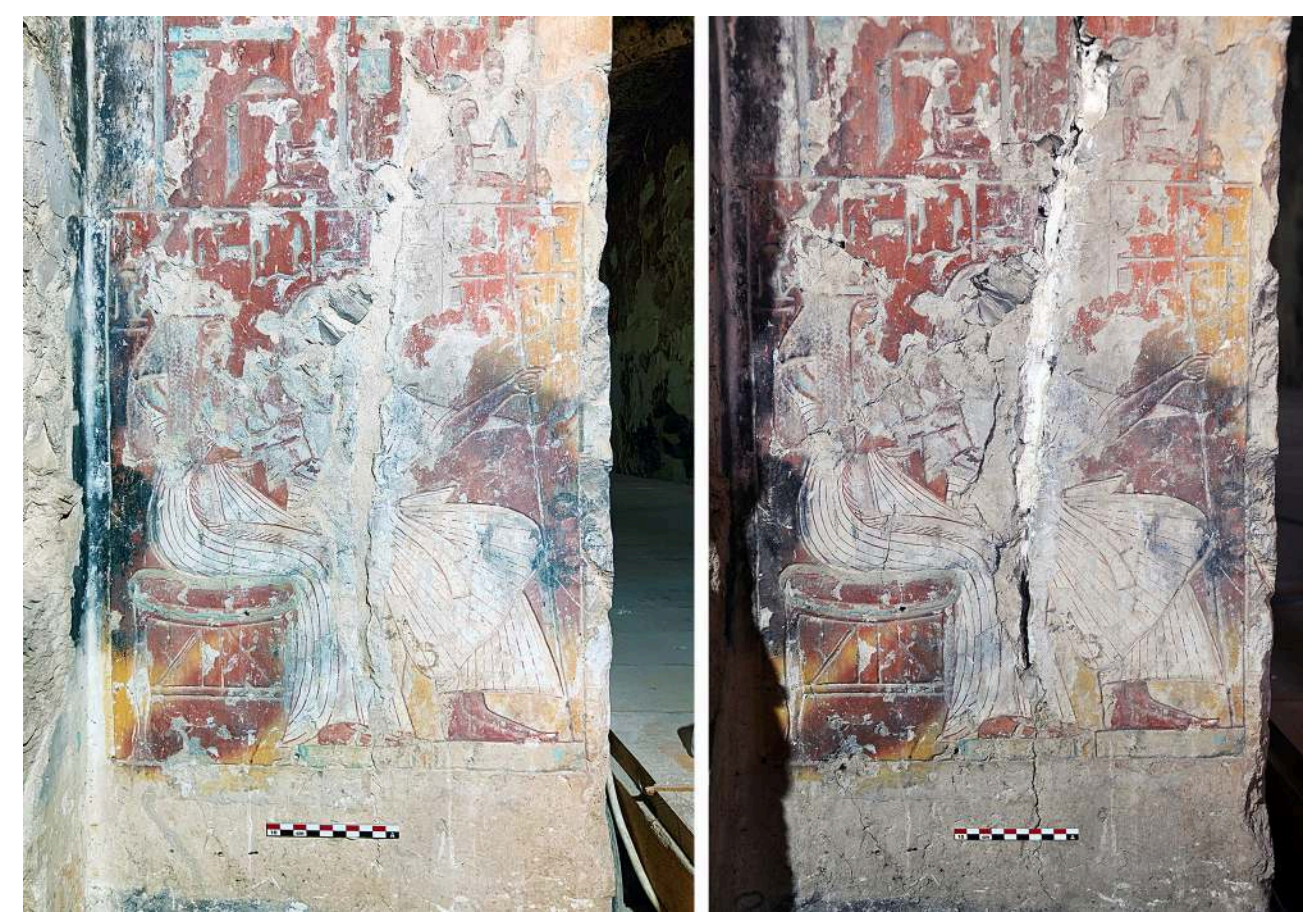

(C) Ifao. 17148_2020_NDMPF_004, 17148_2020_NDMPF_005

\subsubsection{Restauration du mobilier et des décors en pierre}

La restauration des décors et des statues en pierre a concerné un haut-relief représentant un porte-enseigne, un socle indépendant, le traitement des éléments d'architecture extérieurs, le pavement du trottoir nord devant la façade de la tombe et un fragment de «chapiteau ». À cela s'est ajoutée la poursuite de l'intervention sur le bas-relief sud de l'entrée, amorcée lors de la mission de 2019.

\subsubsection{La statue porte-enseigne de Pached}

Lorsque B. Bruyère dresse la liste des sculptures présentes dans la tombe TT 216 dans les années 1920 s'y trouvaient deux porte-enseignes à l'effigie de Pached, le frère de Néferhotep, propriétaire de la tombe. À présent, seul un des deux porte-enseignes est encore présent dans la chapelle. La seconde sculpture est conservée dans les entrepôts du magasin Carter. Elle représente Pached, le pied gauche en avant (attitude de la marche), tenant dans chaque main un étendard gravé d'une colonne de hiéroglyphes (fig. 5). Le pagne à devanteau triangulaire porte également une colonne de texte. 
Fig. 5. Monument porte-enseigne de Pached conservé dans la chapelle de la TT 216 (I. Ibrahim Mohamed).

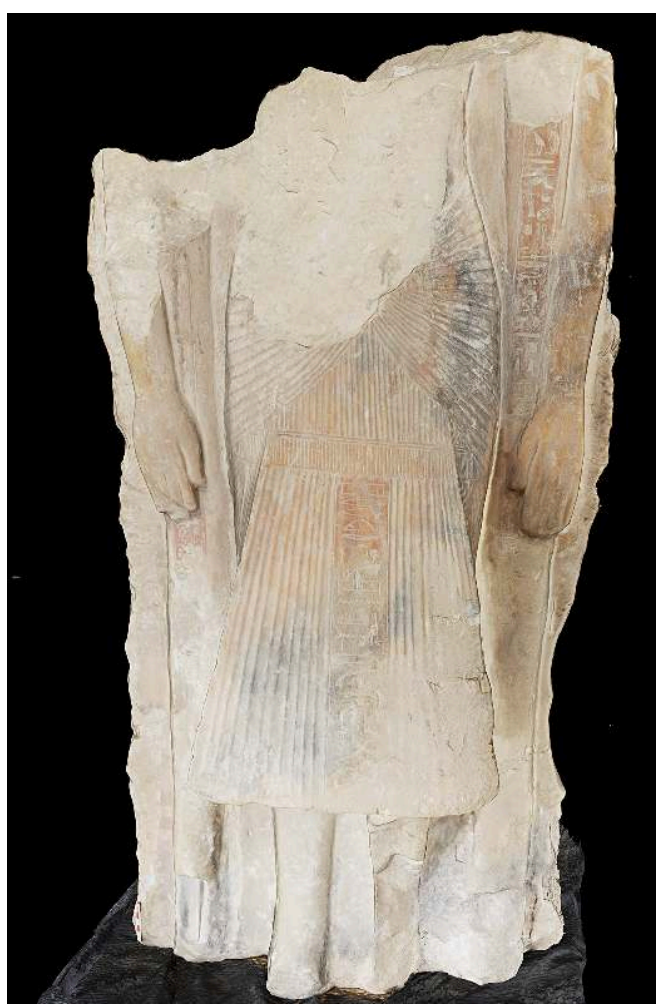

(C) Ifao. 17148_2020_NDMPM_001

La présence de ces deux sculptures monolithiques monumentales à l'effigie d'une autre personnalité que le propriétaire de la tombe pose question. L'endroit où B. Bruyère les a trouvées, de part et d'autre du passage menant dans le couloir, ne s'accorde pas avec les traces de décor qu'on trouve à cet endroit. Cette bizarrerie a conduit les restaurateurs de la mission à analyser de manière rigoureuse le relief porte-enseigne encore présent dans la tombe. Plusieurs indices matériels indiquent que ce relief était intégré à l'origine à une structure architecturale. La présence de résidus de mortier ainsi que des marques et traces d'outils d'aplanissement au revers de la sculpture montrent que le porte-enseigne était encastré, à un moment donné, dans un mur au moyen d'une maçonnerie. Ceci rappelle la même technique employée pour des stèles et bas-reliefs intégrés dans des architectures à la même période.

La sculpture présente de nombreuses traces d'outils allant du dégrossissage à la finition. La prise d'empreintes à différents endroits sélectionnés permettra de procéder à une identification du panel d'outils utilisé lors de la taille. Aujourd'hui, seuls $50 \%$ de la polychromie originale est conservée. Toute la partie supérieure de la sculpture est manquante. La partie inférieure est aussi lacunaire sur le devant: les pieds ont été détruits. De manière générale et d'un point de vue structurel, la sculpture est stable et ne présente pas de risque de nouvelle perte de matière. En revanche, les enduits ainsi que les bouchages antiques sont de faible dureté et nécessiteraient une intervention de consolidation afin de renforcer leur résistance au toucher et de permettre leur préservation pour étude ou prélèvement éventuel. 


\subsubsection{Le socle monumental}

$\mathrm{XIX}^{\mathrm{e}}$ dynastie. Sa conservation est donc primordiale pour l'étude de la tombe dans son ensemble. Cependant, il est devenu extrêmement fragile depuis la fouille archéologique qui a permis de le mettre au jour. Il a fallu intervenir de manière urgente lorsque l'équipe de la mission a remarqué une nette progression de la fragmentation des pierres et donc une accélération du processus de dégradation d'une mission à l'autre. Celle-ci s'illustre par des formes de dégradation variées allant du feuilletage de surface au détachement de fragments de taille plus ou moins importante. Un déblaiement délicat à l'aide d'un pinceau a permis d'identifier les fragments mobiles. La plupart de ces fragments présentaient une bonne cohésion en eux-mêmes, il a donc été possible de les réassembler par collage.

Lors du travail sur les trottoirs, nous avons nettoyé le sol devant la porte d'entrée de la chapelle. Nous avons découvert sous le sable le seuil de la porte d'entrée de la tombe et un pavement partiellement préservé fait de pierres calcaires taillées (fig.6). Il est évident que la qualité de ces pierres n'est pas du tout la même que celle de la montagne dans laquelle la tombe de Néferhotep a été taillée. Il est probable qu'elles ont été 
débitées ailleurs et transportées ensuite jusqu'à Deir el-Médina, à moins qu'il ne s'agisse d'un remploi. Ces pistes de réflexion seront explorées l'année prochaine.

Fig. 6. Pavement de l'entrée après nettoyage (à gauche vers l'est : seconde cour ; à droite vers l'ouest : entrée de la tombe) (C. Larcher).

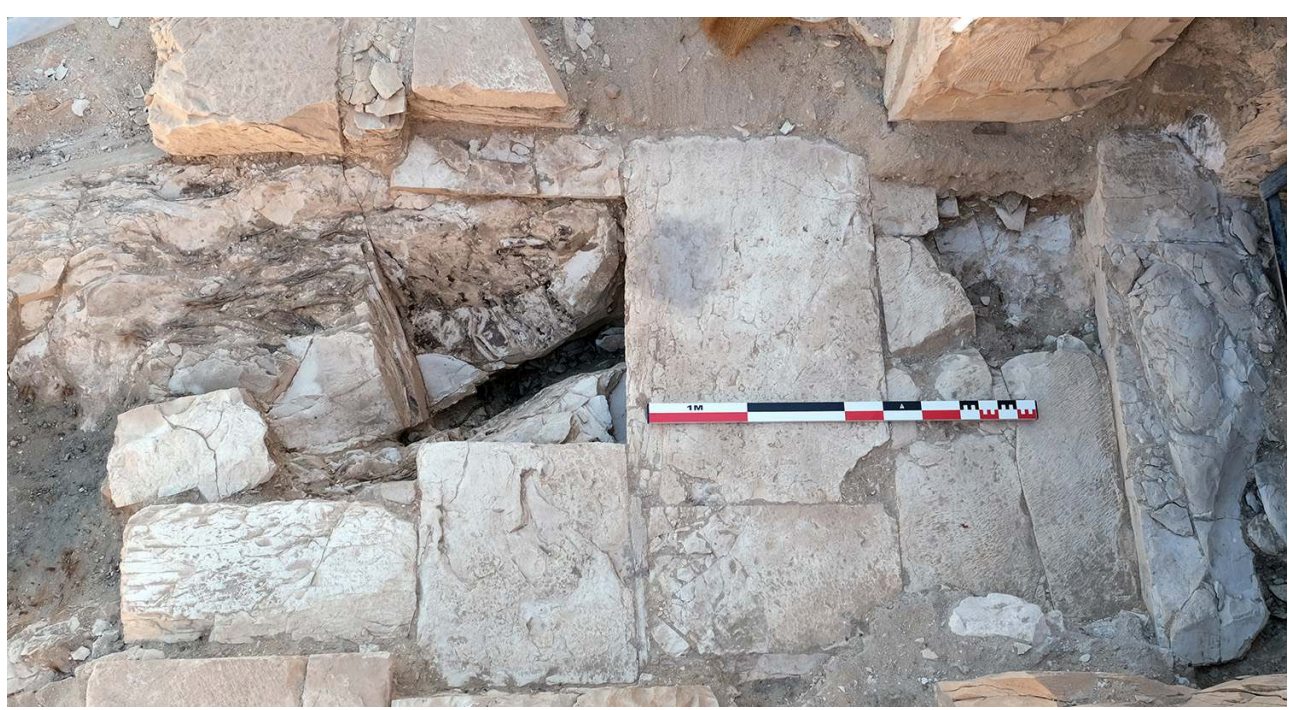

(C) Ifao. 17148_2020_NDMPF_003

\subsubsection{Le chapiteau} B. Bruyère décrit dans les années 1920 comme un chapiteau polychrome. Mais l'encoche encore visible pourrait avoir servi à recevoir une charnière de porte. La question de son appartenance réelle à l'architecture originelle de la tombe TT 216 doit encore être étudiée. en profondeur pour retirer le sable pris dans les fissures, les ouvertures les plus traversantes ont pu être localisées. La première étape de consolidation a consisté à injecter de l'époxy liquide, ceci en raison du poids de la pièce et de son caractère structurel au sein de l'architecture de la tombe.

\subsubsection{Le bas-relief sud}

31 Planifié en 2019, le traitement du bas-relief sud de l'entrée de la tombe a été poursuivi durant la mission de 2020. Certains petits fragments restaient encore mobiles. Ils ont tous été collés à l'ensemble. La consolidation de la face sculptée a été poursuivie. La résistance du bloc de pierre étant tributaire d'une cohésion d'ensemble de sa matière, toutes les ouvertures pouvant être accentuées par la pression du sable et de détritus ont été remplies par injection de mortier liquide.

mission 2020 a permis de progresser dans les travaux entamés les années précédentes tout en déployant de nouveaux ateliers de travail. Dans la chapelle d'abord, dont les travaux de consolidation et de nettoyage avancent dans un échange permanent entre égyptologues et restaurateurs ce qui permet d'optimiser les observations et donc les traitements à mettre en œuvre. Ce travail s'inscrit 
nécessairement dans un temps long d'étude des parois, de la compréhension du programme iconographique, des altérations qu'il a subies, des particularités de chaque zone à traiter, demandant un patient travail de collecte de données primaires. Au-delà des contraintes, les résultats obtenus en ce qui concerne la restauration sont extrêmement positifs. Un frein a été mis à la dégradation continue des enduits et de la couche picturale. Dans de nombreux secteurs de la tombe, l'adhésion aux parois des différentes couches de lissage et de préparation - leur cohésion même - a été renforcée. La structure en a été consolidée et le visuel s'améliore d'année en année.

La mission 2021 devrait permettre de finaliser le traitement de la paroi sud de la salle transversale et de progresser au niveau de la paroi ouest de la même salle. Dans le couloir, le programme iconographique de la paroi sud est de mieux en mieux connu, même si les lacunes empêchent encore d'en avoir une véritable vue d'ensemble. Néanmoins, les progrès ont été spectaculaires, notamment dans la «découverte » de détails permettant d'éclairer en partie l'objet porté en procession dans le tiers oriental de la paroi. Ces détails n'ont pas été notés par B. Bruyère dans ses journaux de fouille. La paroi nord va, elle, devenir un chantier important lors des missions futures.

Outre la chapelle, le déploiement de l'équipe de restauration égyptienne à l'extérieur, dans la seconde cour, autorise un certain optimisme quant à la finalisation de la consolidation des enduits des murs dans un avenir proche.

\subsection{TT 298 - Tombe de Baki et Ounnefer}

The research project concerning the Theban Tomb 298 of Baki and Wennefer, led by Elisa Fiore Marochetti, origins from the Action spécifique 17437 Livre de Morts de Baki (pBaki Turin Cat. 1827/1 + IFAO Inv. $289+290$ ). The papyrus with texts of the Book of the Dead from the Deir el-Medina tradition that was found in fragments in this tomb, belongs to the chief of workmen Baki, dating from the reign of Seti I, and is kept in the Egyptian Museum of Turin ${ }^{2}$ and in the Archives of the IFAO. ${ }^{3}$

During her work at IFAO to recompose the papyrus fragments stored at the IFAO Archive, E. Fiore Marochetti could see the photographic documents concerning the tomb. Photos revealed conspicuous number of human remains and other material scattered in the chambers accessible from shaft 298. It therefore seemed appropriated to request the authorisation to clean and study the tomb in order to check whether papyrus fragments are still present and at the same time to study the architecture, the decoration of the funeral chambers and the chapels, the remains of the material culture through the finds resulting from the operations of cleaning, as well as to seek the objects that were found in the tomb in the previous excavations and kept in storerooms. Authorization has been granted this year only for the cleaning and the study of the tomb complex.

The place of worship in the funerary complex of TT 298 consists of a chapel in the north and a pyramid in the south. B. Bruyère described the north chapel as a mastaba-type structure crowned by a gorge frame and with a vaulted interior room accessible from the middle of the eastern larger side. Only the lower courses of the stone wall of the chapel are preserved so it is difficult to ascertain/verify on what basis B. Bruyère provided this description (fig. 7). ${ }^{4}$ The southern sector of the north chapel has been cleaned up to the original whitewashed floor (fig. 8). Many fragments of the whitewashed wall plaster, with part of the surface in light yellow ocher color, set on 
mouna and once covering the stone wall, have been recovered fallen on the floor (fig. 9).

Fig. 7. TT 298 North Chapel (I. Ibrahim Mohamed).

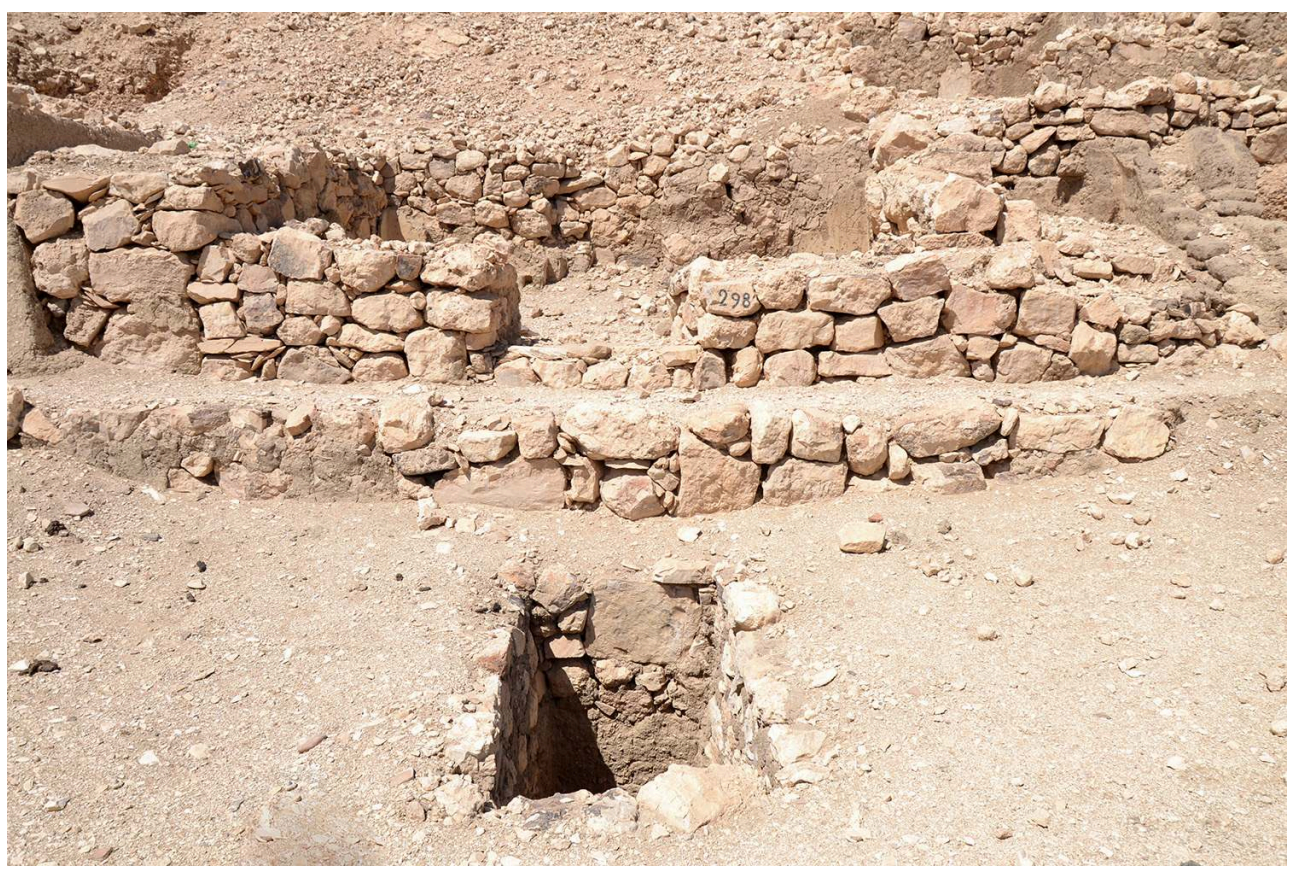

(c) Ifao. NU_2015_01166

Fig. 8. TT 298 North Chapel. The whitewashed floor and part of the wall paintings fallen on the floor in the southern sector (E. Fiore Marochetti).

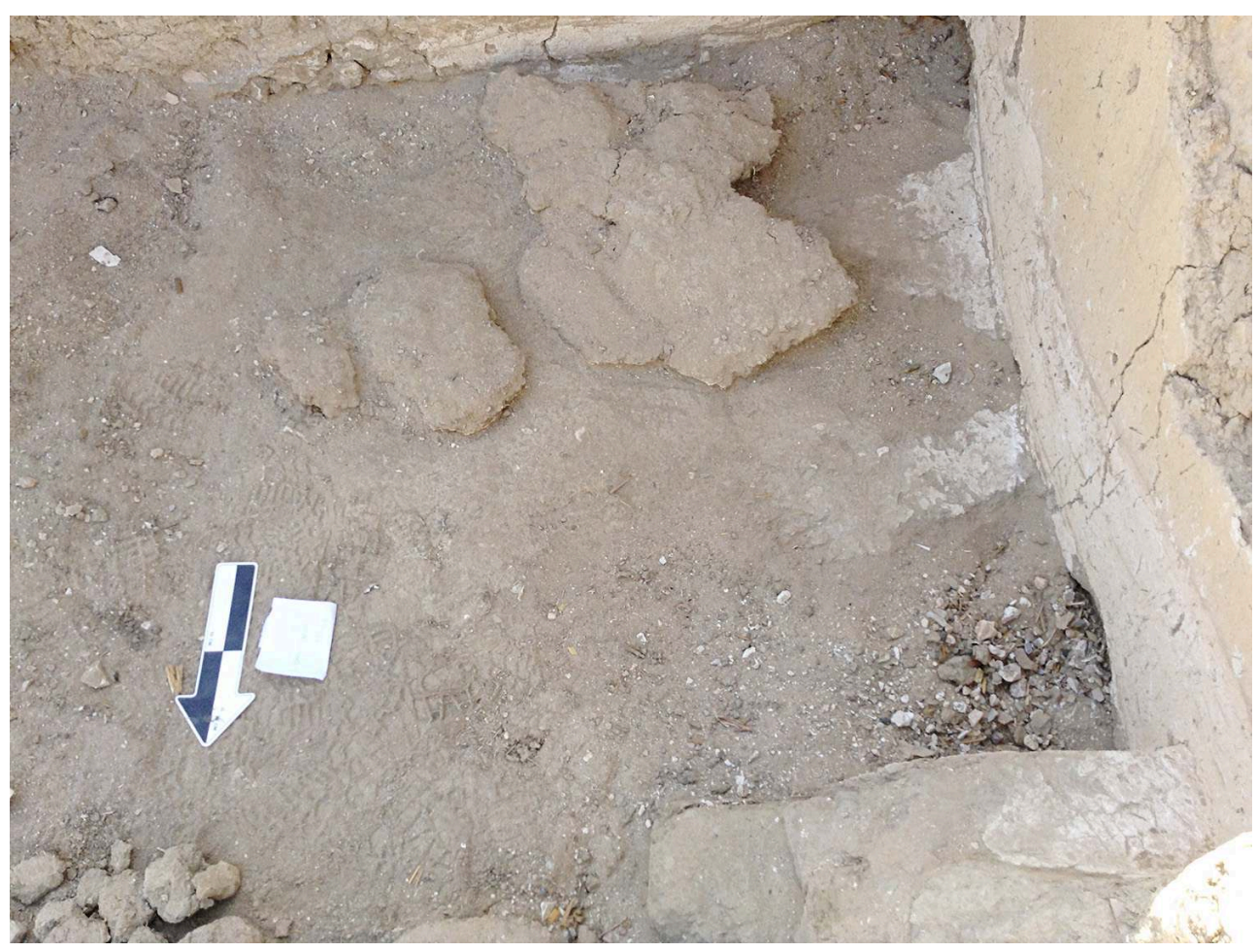

(C) Ifao. 17148_2020_NDMPF_006 
Fig. 9. TT 298 North Chapel. The operations of the restorer Mohamed Youssef Sedek (Misr University for Science and Technology, Egypt) to remove a large fragment of wall paint collapsed on the floor in the southern sector (E. Fiore Marochetti).

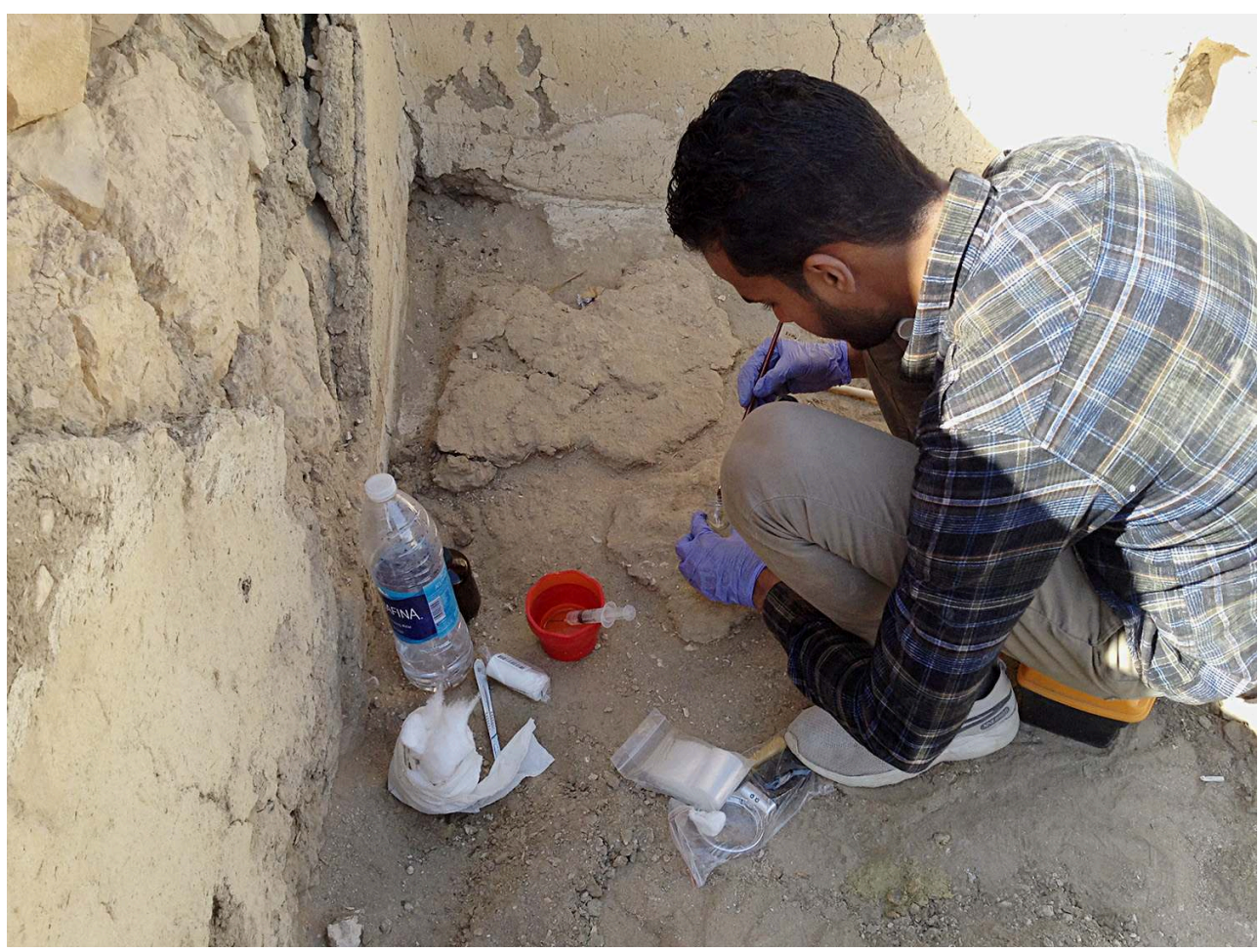

(C) Ifao. 17148_2020_NDMPF_007

The remains of the whitewashed mouna statue described by B. Bruyère ${ }^{5}$ to the right side of the central niche were also freed and cleaned from the layers of sand (fig. 10). The feet and part of the legs on a base are still visible. What was left of the statue in the central niche could also be cleared. A very small portion of the lower-level painted wall plaster with the original colors is preserved in the niche wall: black horizontal stripes alternate with red and yellow ones. The torso and the gown of two men at the side of the statue, described by B. Bruyère ${ }^{6}$ and whose legs only were still visible until 1979, have now completely disappeared. ${ }^{7}$ A stone slab, stuccoed with white plaster, was set in front of the statue forming a step. Another slab was placed to the side of this after the restoration of the northern sector in the second half of 2oth century. Comparing today's situation with B. Bruyère's photographs one can see that the whole northern sector was filled with sand later on after 1927. In the north sector, the modern north-west wall in particular has been consolidated under the supervision of Hassan el-Amir, restorer of Ifao, because it proved to be unstable as it rests on pit 1111 of the 18th dynasty. 
Fig. 10. TT 298 North Chapel. The remains of the whitewashed mouna statue and the decoration of the central niche (E. Fiore Marochetti).

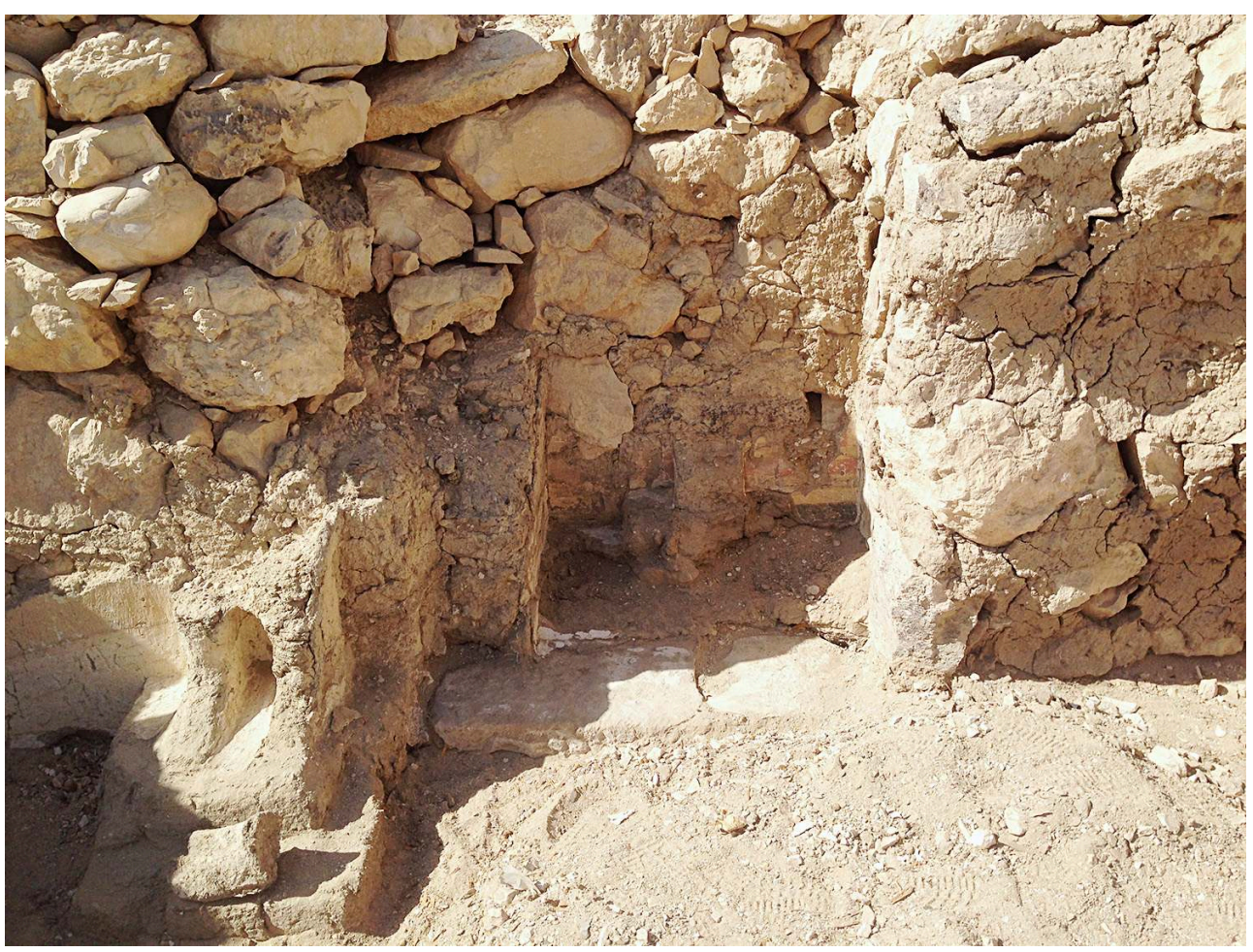

(C) Ifao. 17148_2020_NDMPF_008

In 1927, B. Bruyère had emptied and closed pit 1115 next to 298, leaving the latter filled with human remains apparently as it was found in 1917. Cleaning operations are now underway in the rooms accessible from pit $298 .{ }^{8}$ The funeral chamber named $C$ in the B. Bruyère relation, ${ }^{9}$ chamber $B$, and part of the $D$ were cleaned and sieved (fig. 11). The funeral chamber, the only one lined with bricks and decorated, has been emptied in the past and the bodies amassed in the other chambers mixed with other burials laid there. The findings consist of fragments of painted wooden coffins, pottery, linens. To this a number of fragments of painted plaster decorated with decorative patterns is added, which was found fallen on the floor of the decorated funeral chamber: these were part of the embalming scene with the deceased on the bed, Anubis, Isis and Nephtys painted on the north wall. These fragments can partly complete the wall decoration (figs 1213). Unfortunately, no papyrus fragments have been found so far. 
Fig. 11. TT 298 funeral chamber C: fragment of the eye of the goddess Isis from the decoration of the north wall found on the floor (E. Fiore Marochetti).

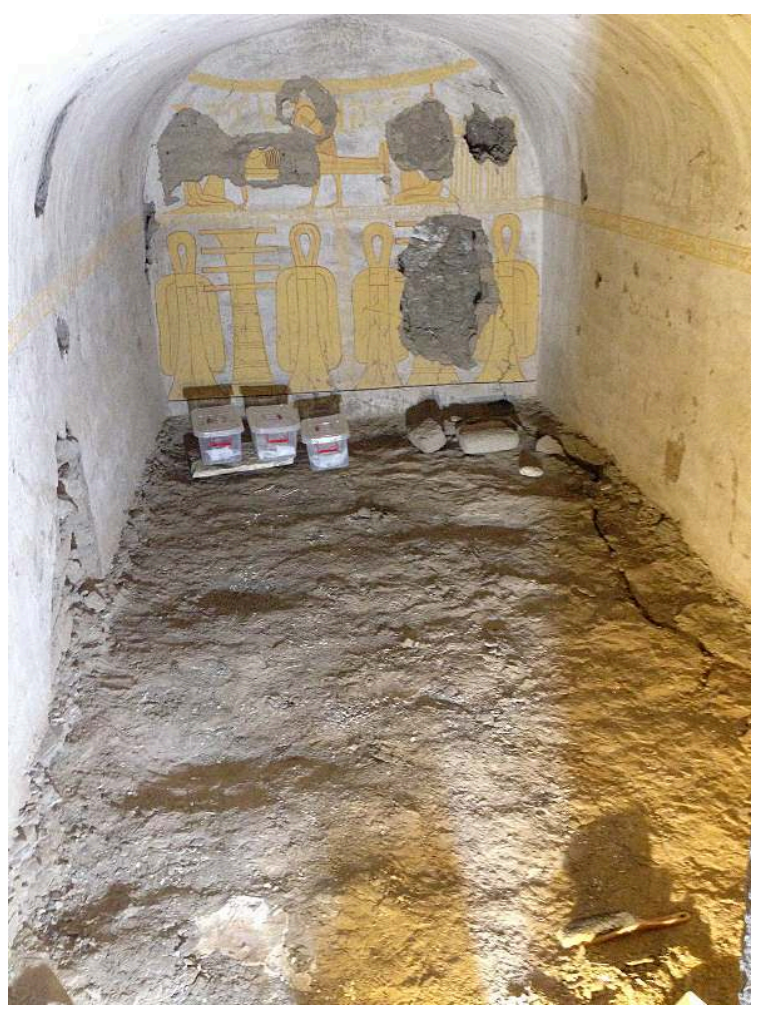

(C) Ifao. 17148_2020_NDMPF_009

Fig. 12-13. TT 298 North wall. Virtual rendering of the recomposition of the mummy's eye with a fragment found on the floor. before a) and after b). (E. Fiore Marochetti).
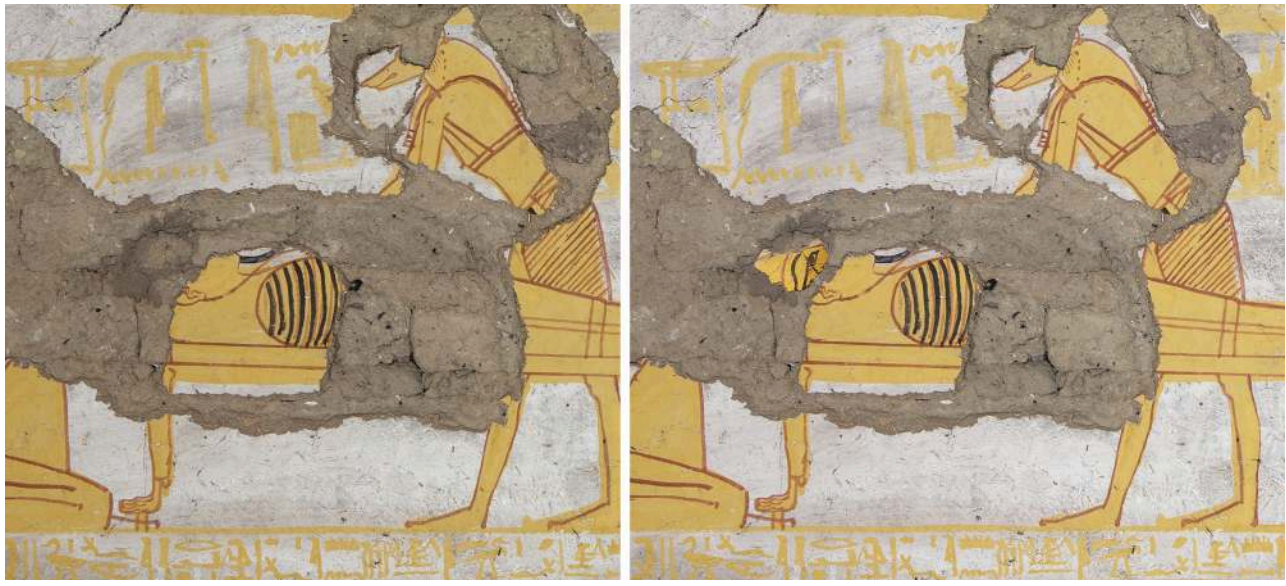

(c) Ifao. 17148_2020_NDMPF_010, 17148_2020_NDMPF_011 remains of bandages and shrouds that enveloped the human remains, of which thirteen boxes have been filled by the team of anthropologists operating at the same spot, still need to be checked.

In addition to numerous bones and linen, a bread and a leather sandal, we will emphasize the presence of objects of small dimensions (very small pearls, fragments of painted wooden coffins, baskets, ropes), which complete the small material. Finally, a 
number of sherds of pottery were discovered. Most of it was photographed, so to give an initial expertise as to their dating in order to assess whether they provide additional clues to the different phases of occupation of the tomb.

The main problem that arose during the activities concerns the preservation of the structure and the decorative apparatus. Cleaning, consolidation of wall plasters, and relocation of the fragments on the wall, where possible, as well as monitoring of rock and embankment stability with the identification of the chambers now inaccessible from pit 1115, as filled in with sand, and of pit 1111 under the north chapel would therefore be necessary in the next future.

\subsection{TT 340 - Tombe d'Amenemhat}

À la demande du Conseil Suprême des antiquités, la TT 340 a été restaurée par la mission. Cette tombe, creusée et décorée pour Amenemhat, un ouvrier de Deir elMédina qui a vécu au début de la XVIII ${ }^{e}$ dynastie, est sans doute la plus ancienne de la nécropole de l'ouest. Découverte en 1925 par B. Bruyère, elle est composée d'une petite cour, aujourd'hui en grande partie détruite et d'une chapelle rectangulaire voûtée de 2,20 m de long sur 1,55 m de large pour une hauteur de 1,63 m. Youssef Mohamed Sedek et Manon Lefevre ont assuré la restauration de la chapelle. Un relevé photogrammétrique des parois de la chapelle a été réalisé par Ihab Ibrahim Mohamed avant la restauration.

La chapelle n'avait jamais été restaurée, la seule intervention majeure antérieure a constitué en la pose d'une porte d'entrée pour protéger l'intérieur, à une date indéterminée. En comparant l'état actuel du décor avec les photographies anciennes prises par B. Bruyère dans les années 1920 puis celles de la campagne photographique réalisée en 1969, les restaurateurs n'ont pas constaté de dégradation préoccupante. Les altérations observées sont majoritairement des lignes de fracture et des craquelures dans la couche picturale qui étaient déjà présentes lors de la découverte de la tombe. Elles sont dues principalement au mouvement de la montagne thébaine dans laquelle la tombe a été creusée. Ce phénomène naturel impossible à maîtriser exerce une pression sur les murs des tombes souterraines et provoque des fissures de plusieurs dizaines de centimètres. La couche picturale encore en place est plutôt en bon état, malgré la présence de nids de guêpes maçonnes qui ont colonisé des recoins de la tombe. Des destructions humaines volontaires effectuées aux époques anciennes sont aussi visibles sur certaines parties des décors. C'est le cas par exemple des yeux et des visages des personnages qui ont été systématiquement grattés à une époque indéterminée. Autour de toutes ces dégradations, la peinture adhère moins à la paroi et avec le temps des petits fragments se morcellent et finissent par tomber érodant peu à peu la couche picturale. Dans un premier temps, les restaurateurs ont retiré mécaniquement les résidus de nids d'insectes. Ils ont ensuite injecté un produit consolidant (PLM-Al) dans les fissures afin de renforcer la solidité des différentes couches de la stratigraphie sous la couche picturale. Des joints permettant d'empêcher la perte de matière, de renforcer l'adhésion des couches entre elles et d'en assurer l'étanchéité ont été posés. Les plus grosses fractures ont été rebouchées avec un enduit de restauration. En dernier lieu, un palier et un escalier en bois ont été posés devant l'entrée de la chapelle afin d'en sécuriser l'accès. Une faille apparue en raison du déplacement naturel de la montagne, à une date que ne nous pouvons déterminer, posait des problèmes de sécurité. Plutôt 
que de la boucher avec du ciment, du sable ou des pierres, ce qui aurait exercé encore plus de pression dans les anfractuosités et contribué à l'instabilité de la zone, il a été décidé de créer une structure en bois qui l'enjambe.

\section{2. Études du mobilier stocké sur le site}

La mission a poursuivi l'inventaire et le catalogage systématique des objets stockés dans les magasins 23 (puits 1049) et 25 (devant la TT 336). 1846 objets ont été traités : du mobilier en bois funéraire et domestique, des figurines en céramique représentant des femmes allongées, des animaux variés ou des êtres hybrides, des ostraca figurés et inscrits, des appuis-tête, des fragments de stèles, des pinceaux et des bols contenant des pigments écrasés pour fabriquer de la peinture. Toutes les données relatives à ces inventaires ont été déposées au service des archives et collections de l'Ifao.

\subsection{Le mobilier en bois}

La troisième mission d'étude des bois de Deir el-Médina dirigée par Gersande Eschenbrenner Diemer, s'est déroulée du 13 janvier au 13 février 2020. Son objectif était d'étudier le matériel conservé dans la TT 217 et le magasin 23.

L'inventaire du matériel stocké dans le magasin, rouvert en 2019, a été réalisé par Anna Giulia de Marco, Lisa Sartini et Paolo Marini. Plusieurs centaines d'objets en bois, qui avaient été classés par typologie dans les années 1950, ont ainsi été nettoyés et réorganisés par catégories: statues, récipients, meubles, boîtes, éléments décoratifs, outils, objets à caractère funéraire ou religieux et pièces encore indéfinies.

Pendant les deux premières semaines, l'équipe s'est concentrée sur les articles de toilette afin de préparer la publication prochaine de ce matériel. Peignes, épingles à cheveux, pot et bâtons à khôl ont d'abord été nettoyés puis enregistrés et photographiés. 364 peignes ont ainsi été inventoriés (DeM_2020_M23_500 à DeM_2020_M23_864). Bien que majoritairement fragmentaires, ces derniers avaient conservé des éléments de décor significatifs qui ont permis d'en dresser la typologie (fig. 14). Cette typologie, définie en fonction de leur bordure et de leur décor de face, a permis d'identifier treize types de peignes. Tous les peignes ont été échantillonnés par G. Eschenbrenner Diemer afin de compléter l'analyse globale de ce mobilier et comprendre les modes d'utilisation des essences de bois employées pour leur fabrication. Ces échantillons seront analysés au microscope optique lors de la mission 2021. L'équipe a ensuite procédé au nettoyage, à l'enregistrement et à la photographie de plusieurs pots à khôl, bâtonnets à khôl et épingles à cheveux, soit 96 objets inventoriés sous les numéros suivants: de DeM_2020_M23_865 à DeM_2020_M23_961. Comme pour les peignes, toutes les épingles à cheveux ont été classées en fonction du décor gravé en partie supérieure et sur la tige. Deux types ont ainsi été définis et déclinés en quatre sous-types en fonction de leur décoration. 
Fig. 14. Peigne, inv. DeM2020_M23_732 (G. Eschenbrenner Diemer).

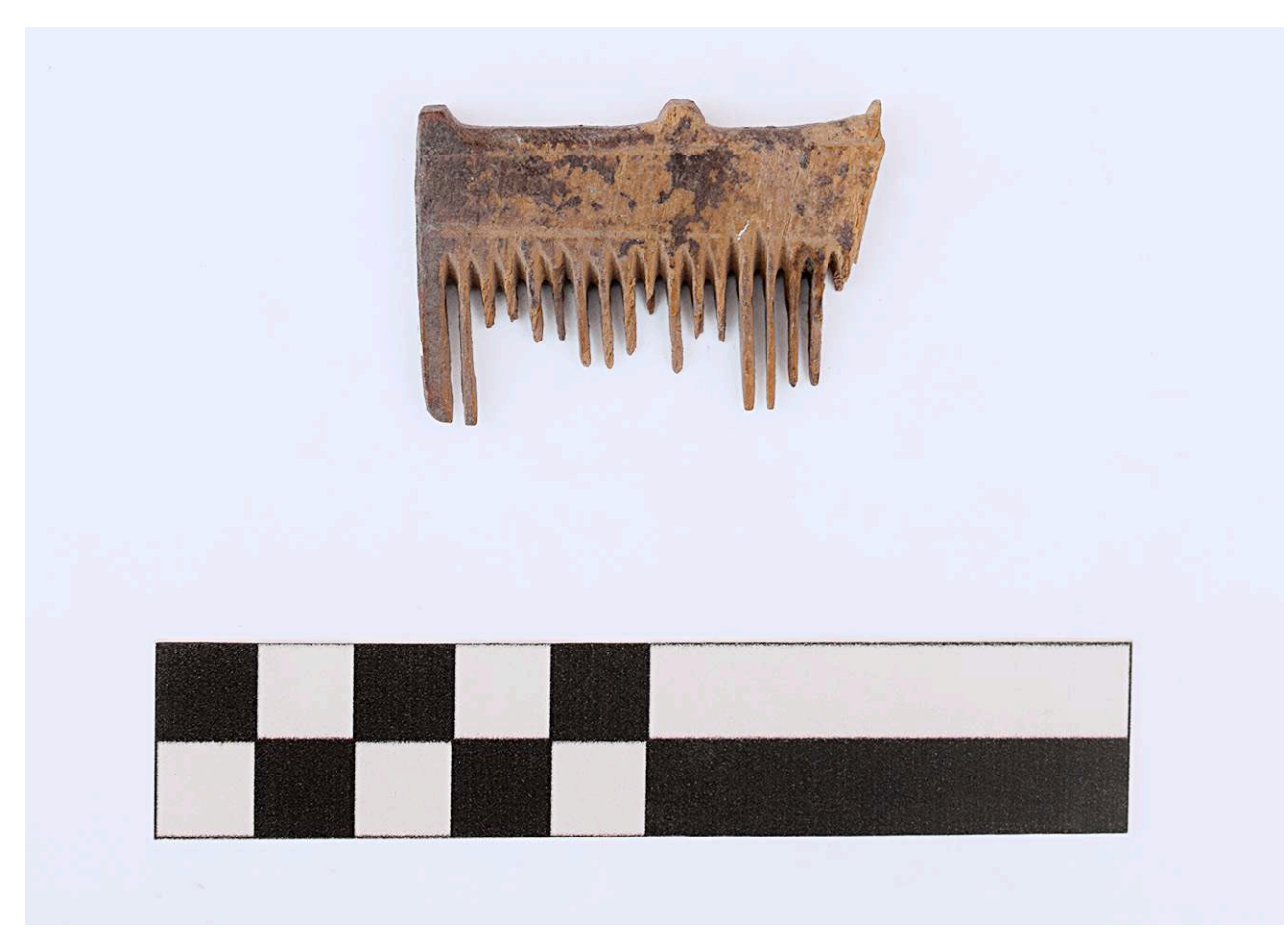

(c) Ifao. 17148_2020_NDMPM_002

49 Les typologies des peignes et des épingles à cheveux en bois seront utilisées pour analyser la collection des objets en bois de l'Ifao et permettront la réalisation d'une publication uniformisée de ces objets.

Parallèlement, les appui-têtes en bois ont été prélevés afin d'identifier les essences employées pour leur fabrication (fig. 15). Ces données seront ainsi intégrées à la prochaine publication de ce matériel (tous matériaux confondus) qui leur sera consacrée. 
Fig. 15. Appui-tête, inv. RT16 (G. Eschenbrenner Diemer).

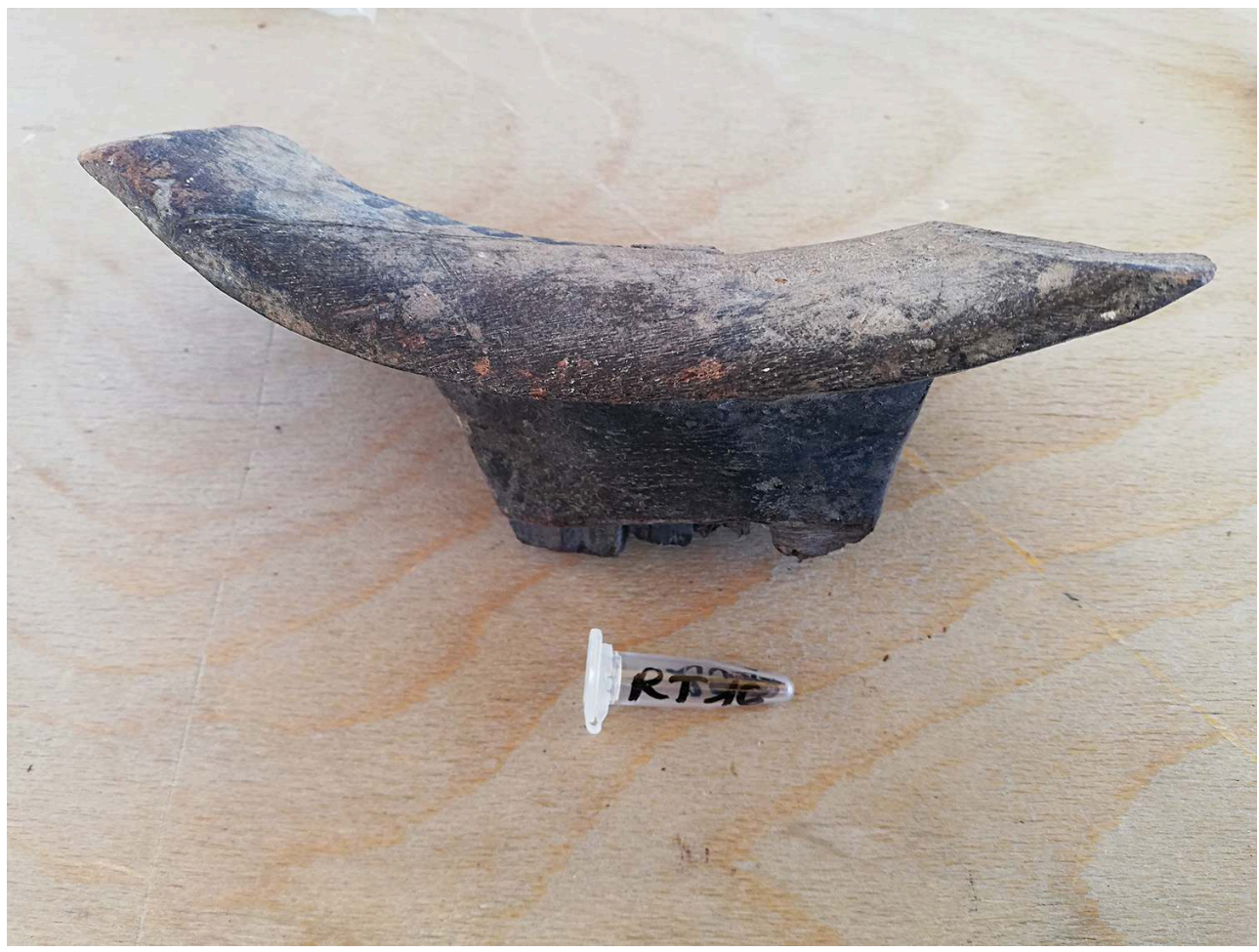

(C) Ifao. 17148_2020_NDMPM_003

51 L'équipe chargée de l'inventaire des bois du puits 1049 a consacré sa dernière semaine de travail au nettoyage, à l'enregistrement et à la photographie de 229 fragments de statues et statuettes (fig. 16) inventoriés du numéro DeM_2020_M23_866A à DeM_2020_M23_891A et de DeM_2020_M23_962 à DeM_2020_M23_1166. Tout le matériel de la fosse 1049, reconditionné dans de nouvelles boîtes, a ensuite été remis en place. 
Fig. 16. Pschent, inv. DeM_2020_M23_875A (G. Eschenbrenner Diemer).

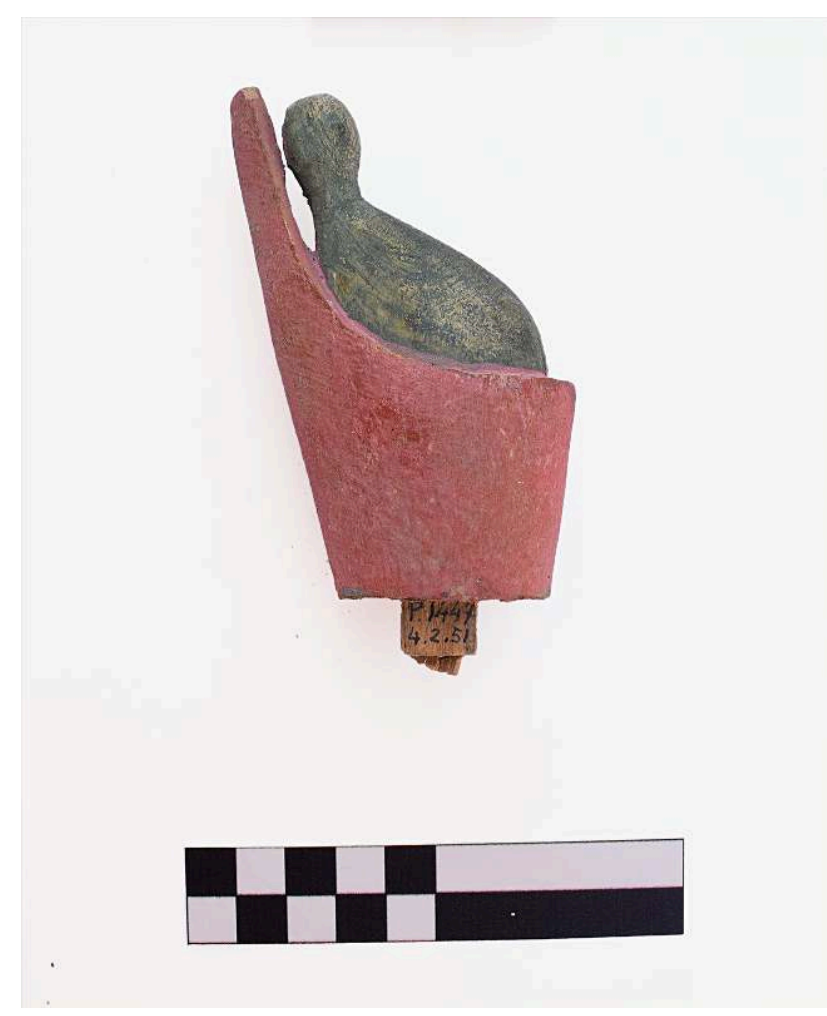

(c) Ifao. 17148_2020_NDMPM_004

52 Parallèlement à ce travail d'inventaire, L. Sartini, M. Serpico et G. Eschenbrenner Diemer ont poursuivi l'analyse des cercueils à fond noir datant du Nouvel Empire : les dessins techniques ont été achevés, les traces de vernis et de résine ont été relevées. Des prélèvements ont été faits dans les planches, les chevilles et les tenons de chaque cercueil. Les lames minces qui en ont été réalisées ont ensuite été analysées et photographiées au microscope optique. Les résultats de cette étude ont été rassemblés au sein d'un article qui a été déposé pour être publié dans le BIFAO.

M. Serpico, égyptologue et spécialiste des produits d'origine naturelle en Égypte ancienne, s'est intéressée aux vernis et résines identifiés sur plusieurs supports (pinceaux et bols). Parallèlement à l'étude des vernis et résines, les différents fragments de bois qui étaient pris dans la résine agglomérée autour du bol M23-1774 ont été prélevés pour être analysés lors de la mission 2021 (fig. 17). 
Fig. 17. Éclats de bois pris dans la résine d'un bol, inv. M23-1774 (G. Eschenbrenner Diemer).

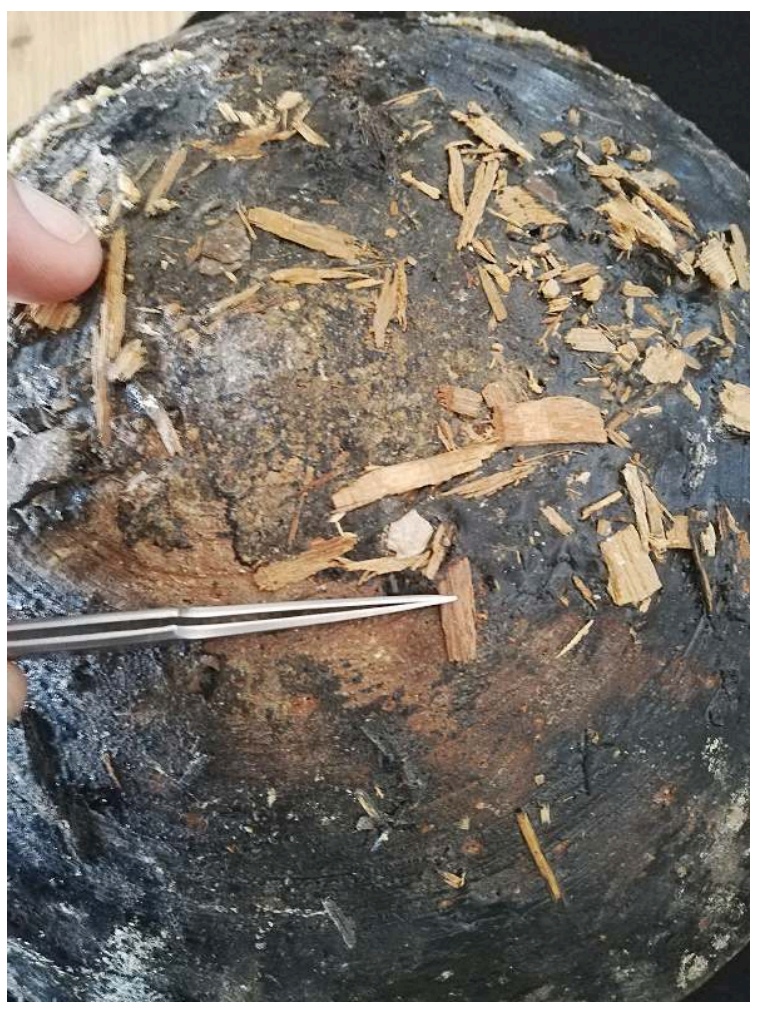

(C) Ifao. 17148_2020_NDMPM_005

\subsection{Le mobilier et les ostraca des magasins $M 23$ et $M 25$}

During the season in 2020 the documentation of the objects within magazine M 25 was done by Julian Posch, Omaïma el-Shal and Huzeifa Magdy. All objects were reorganized and grouped according to their type. Among them are several funerary cones, some of them bearing names of kings, several headrests, fragments of small stela and statues, ostraca and ceramic vessels.

130 headrests were completely inventoried and photographed and will be published as a corpus together with the other known headrests from Deir el-Medina. Some of them are known to come from the excavations in the workmen's huts at the top of the mountain on the way to the Valley of the Kings, but most of them were found in and around the worker's village. Only few of them have decorations or marks on them. Many are known from the Journal de fouilles of B. Bruyère and have a precise find context.

The remaining (unstudied) ostraca inside magazine M 25 were inventoried and documented. ${ }^{10}$ Only few ostraca are left unstudied and will be documented next season. Among the studied ostraca of this year were several bearing exercises both for carving and painting/writing (fig. 18). Some of the carved examples have outstanding and unique motifs on them which will be studied in detail next season. Most of the ostraca from this year's season bear figures well known from other ostraca of this time (fig. 19). They have been photographed for publication. Among the ostraca were several ostraca stela and tablets which seemed to be unfinished. Most of them have only traces of color left. Especially the tablets show clear traces of reuse. 
Fig. 18. Ostraca, inv. DEM_2020_M25_505 and DEM_2020_M25_430 and DEM_2020_M25_581 (I. Ibrahim Mohamed).
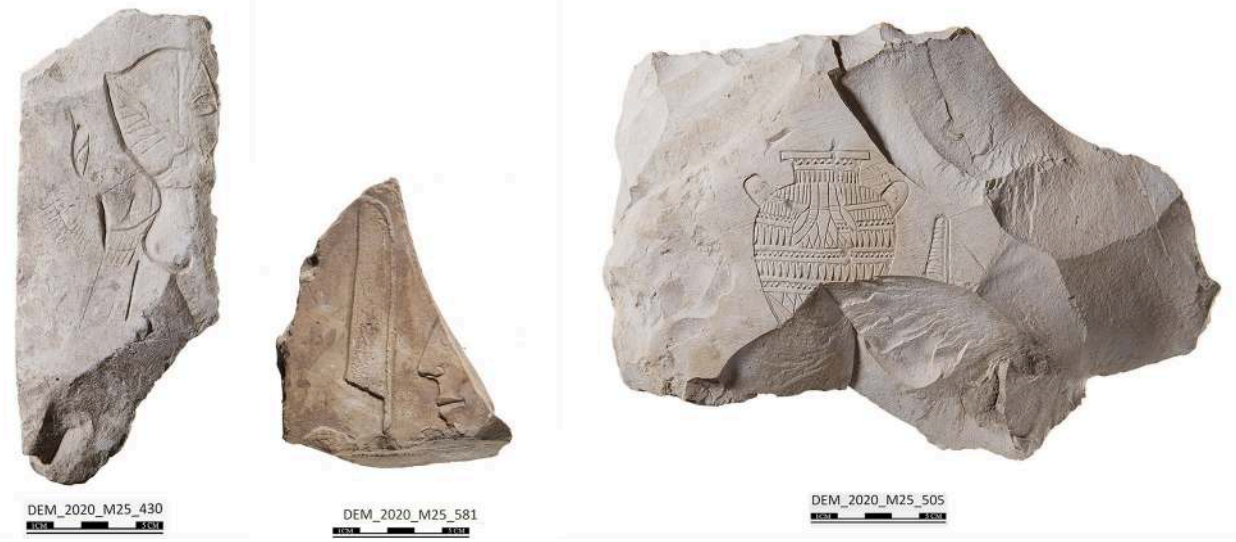

(c) Ifao. NU_2020_02207, NU_2020_02508, NU_2020_02579

Fig. 19. Ostracon, inv. DEM_2020_M25_483 (I. Ibrahim Mohamed).

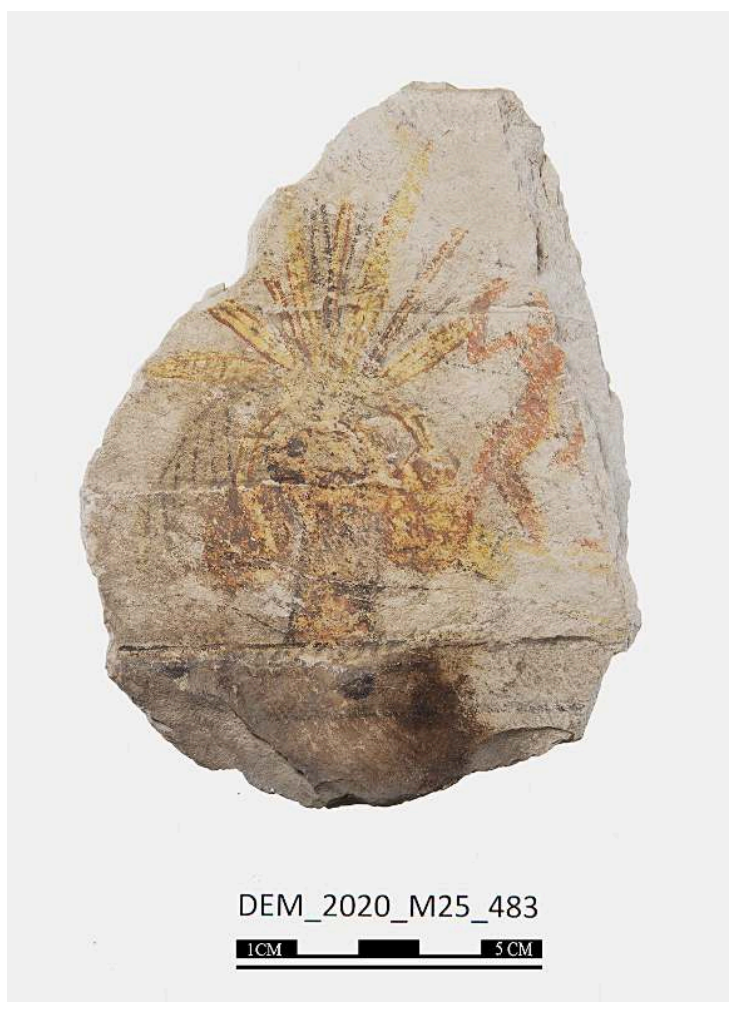

(c) Ifao. NU_2020_02061

57 All documented ostraca are now stored in acid-free envelopes and grouped together in breathable boxes. The most promising ostraca were further photographed using an infrared camera - unfortunately with disappointing results.

Annie Gasse inventoried and studied the brushes that were stored in magazine M 23. Most of them differ in size. Several tips of the brushes were still covered with ink and show clear traces of usage. They are now stored in the magazine M 25 where the conditions of conservation are better. 


\subsection{Le mobilier contenant des marques d'ouvriers} New Kingdom, in which the abovementioned specialists participated. ${ }^{12}$ The project concentrated on New Kingdom ostraca inscribed with the individual identity marks of members of the royal necropolis workforce. Ostraca of this type have been discovered at Deir el-Medina, the site of the workmen's settlement, as well as in the Valley of the Kings and the Valley of the Queens. The same marks are attested on other artefacts found at these sites, such as furniture, cloth, and especially ceramics; in such cases, they seem to be markers of personal or family property. They are also known from numerous graffiti in the Theban necropolis area. Sometimes they occur together with, and even integrated in hieratic texts, but more usually they represent a separate type of notation that was used by semi-literate workmen and administrators. On ostraca, the marks are often accompanied by clusters of strokes or dots, by (pseudo-)hieratic numbers, and by more specific icons referring i.a. to products. By their style, such ostraca betray the hands of persons not fully familiar with hieratic and hieroglyphic writing.

61 Presently the total number of identified relevant ostraca, kept in many different collections worldwide, is more than 1,200. Over 700 of these are presently stored in the Ifao archive, Cairo, and at the site of Deir el-Medina. Very few of the IFAO ostraca with marks have been published so far, in B. Bruyère's excavation reports of Deir el-Medina, as stray inclusions in catalogues of Ramesside hieratic ostraca, and in a recent article devoted to 18 th Dynasty workmen's identity marks. ${ }^{13}$ Visits to the IFAO archive by the research team in 2013, 2014 and 2019 have made it possible to identify and document the relevant ostraca there; during the 2020 mission in Deir el-Medina, additional ostraca kept in local storage could be identified and documented.

A total of 162 objects from storeroom M 25, nearly all limestone and a few potteries, were documented (photos, notes, measurements, material descriptions). This number includes pieces bearing signs of uncertain nature that will be retained pending final selection for the IFAO catalogue. The word "ostraca" is here to be taken in a wide sense, and applies to fragments of stone and pottery bearing one or more marks, but includes for instance limestone jar lids and tags (e.g. fig. 20), possibly also tokens and weights. The function of many pieces being uncertain, the choice has been made to retain such groups, and to present them as such in the catalogue to be published. The pieces were found stored in boxes and on shelves, and a number of them had previously been given inventory numbers. The documented pieces that were still unnumbered received 
inventory numbers during the 2020 mission (numbers DEM_2020_M25_100 to DEM_2020_M25_206).

Fig. 20. Inv. DeM_2020_M25_206.

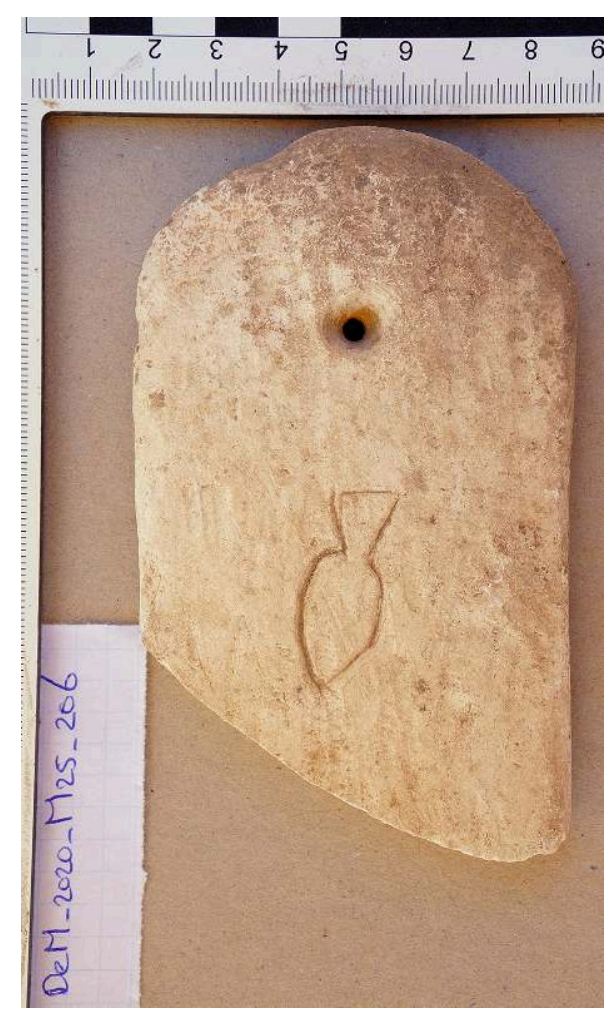

(c) B.J.J. Haring, K.V.J. van der Moezel. 17148_2020_NDMPM_006

By far most of the ostraca whose relevance is certain are of modest sizes (typically with height and width remaining under $10 \mathrm{~cm}$ ), and have one mark only. Such pieces may have functioned as tokens or tags (fig. 21). Marks have been engraved, and/or applied with red or black ink, or with charcoal. Their repertoire includes both Ramesside and 18th Dynasty marks. ${ }^{14}$ Several ostraca show substantial clusters of 18 th Dynasty marks accompanied by dots (e.g. figs 22-23). A clear separate category is that of limestone circular jar lids, each inscribed with one mark, sometimes carved very deeply and neatly (e.g. fig. 24). Similar objects are known from the workmen's huts in the Valley of the Kings. ${ }^{15}$ 
Fig. 21. Inv. DeM_2020_M25_200.

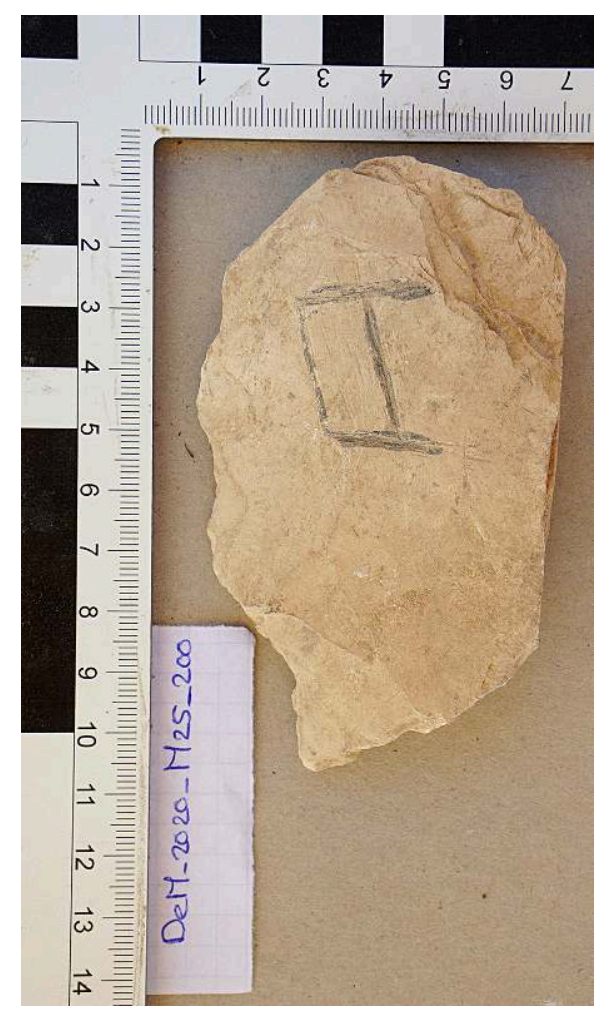

(๖ B.J.J. Haring, K.V.J. van der Moezel. 17148_2020_NDMPM_007

Fig. 22. Inv. DeM_2018_M25_026.

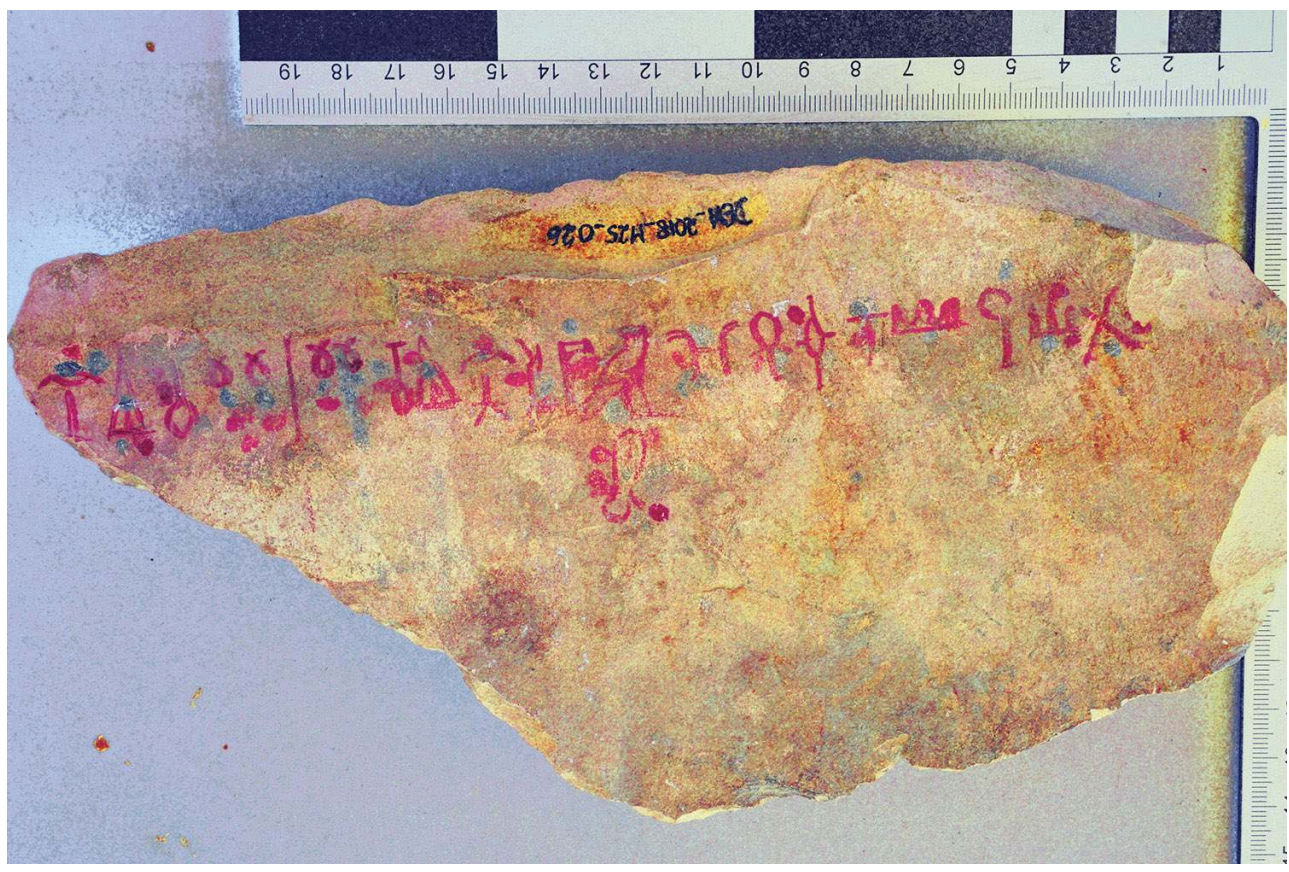

(c) B.J.J. Haring, K.V.J. van der Moezel. 17148_2020_NDMPM_008 
Fig. 23. Inv. DeM_2018_M25_065.

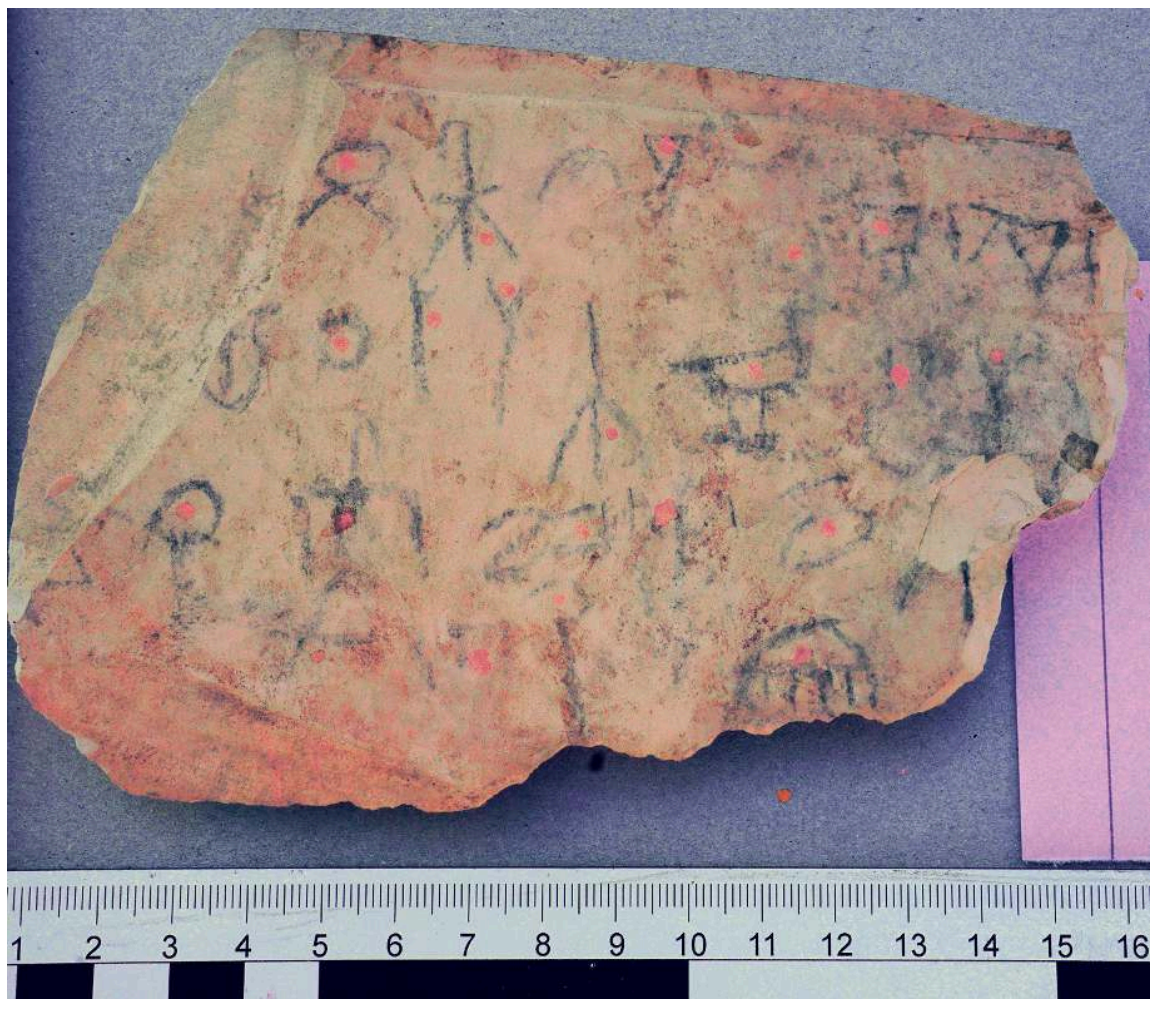

(c) B.J.J. Haring, K.V.J. van der Moezel. 17148_2020_NDMPM_009

Fig. 24. Inv. DeM_2020_M25_146.

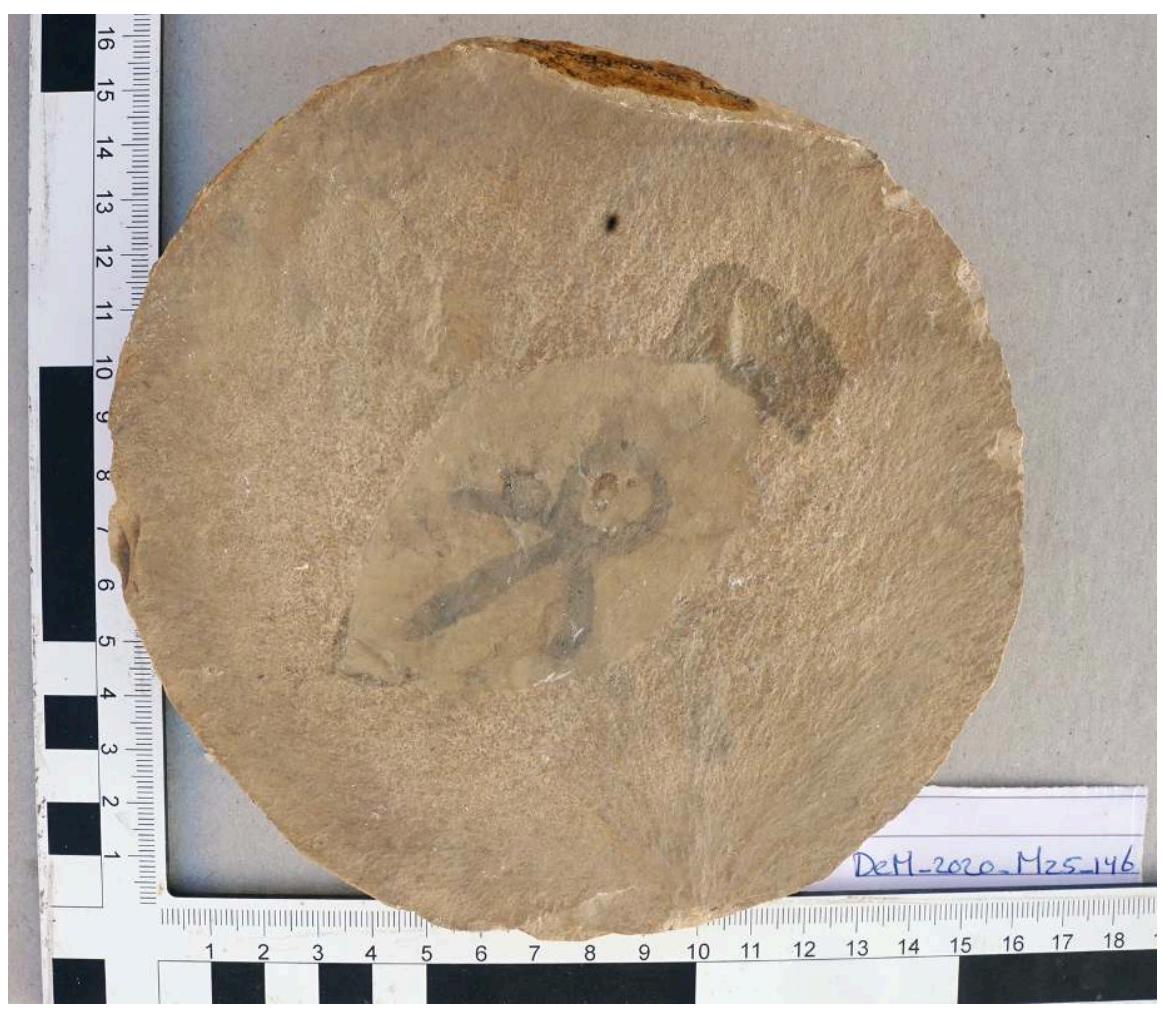

(c) B.J.J. Haring, K.V.J. van der Moezel. 17148_2020_NDMPM_010 
Additionally, workmen's marks have been identified on other artefacts stored in M 25: four of the limestone headrests that were being studied and documented by Julian Posch during the 2020 mission, ${ }^{16}$ and a collection of thirteen stone bullets of unclear nature and function (diameter between 1.7 and $3.1 \mathrm{~cm}$ ), four of which are inscribed with identity marks. Artefacts in M 23 also include marked implements of stone and wood, including a comb ${ }^{17}$ and several dozen spindle whorls, as well as a clay figurine. Only some of the marks on spindle whorls could be identified as workmen's identity marks with certainty. These, however, are not objects for publication in the envisaged IFAO ostraca catalogue.

\subsection{Figurines féminines et matériel ethnographique}

Marie-Lys Arnette conduit un projet de publication des figurines féminines provenant de Deir el-Médina conservées à l'Ifao (action spécifique 18457), qui a pour objectif une meilleure compréhension des croyances et des pratiques entourant la mise en scène de la fertilité au sein de la communauté, et des normes du corps féminin. À ces figurines de femmes viennent s'ajouter d'autres petits objets procédant à priori du champ sémantique de la fécondité - modèles de lits, figurines de Bès, figurines d'hommes en érection, et genitalia (modèles de phallus en érection et sexes féminins) (fig. 25).

Fig. 25. Modèle de phallus en calcaire, inv. DeM_2020_M23_191 (I. Ibrahim Mohamed).

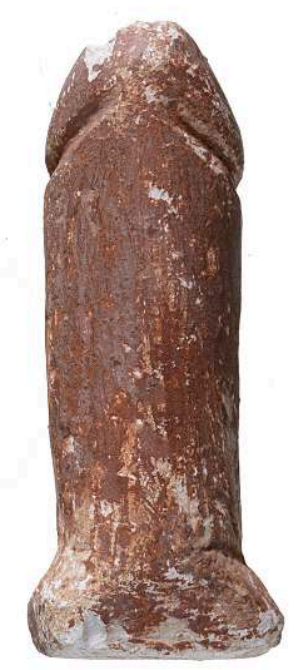

\section{DEM_2020_M23_191 \\ $1 \mathrm{CM}$ \\ $5 \mathrm{CM}$}

C) Ifao. 17148_2020_NDMPM_011

Le magasin M 23 abrite le « matériel ethnographique », selon l'expression employée par Pierre du Bourguet (026838281) qui en a effectué le tri avec Jean Yoyotte (069613559). Il contient 260 figurines féminines et objets associés à la fertilité, qui ont été inventoriés, restaurés et photographiés lors de la mission de janvier 2020. Beaucoup viennent 
compléter les séries des collections conservées au service des archives et collections de l'Ifao, permettant ainsi d'assurer la provenance de ces dernières, quand d'autres objets se sont révélés tout à fait originaux (fig. 26-27). Par exemple, certaines des figurines modelées à la main, sans doute réalisées par celles et ceux qui en avaient usage, montrent des décors de corps inconnus sur ce genre d'objets, mais qui reprennent quasi à l'identique les tatouages arborés par les momies de femmes retrouvées sur le site et étudiées par Anne Austin.

Fig. 26. Femme nue allaitant un enfant (figurine moulée) inv. DeM_2020_M23_056 (I. Ibrahim Mohamed).

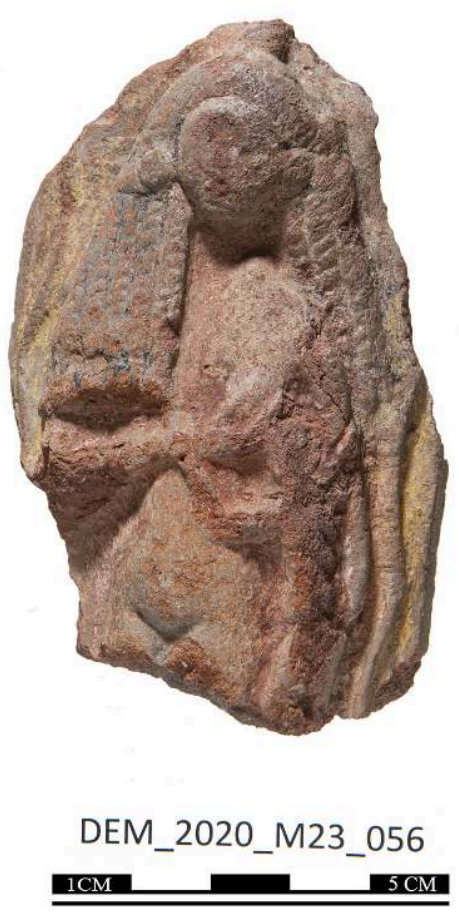

(C) Ifao. 17148_2020_NDMPM_012 
Fig. 27. Femme nue enceinte (figurine modelée à la main) inv. DeM_2020_M23_210 (I. Ibrahim Mohamed).
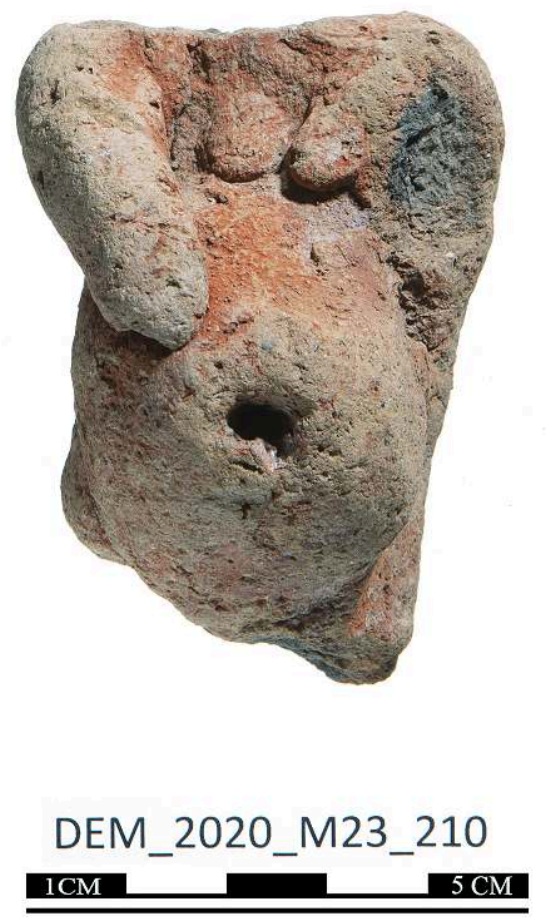

(C) Ifao. 17148_2020_NDMPM_013

Le reste des objets du M 23 a été lui-aussi inventorié : M.-L. Arnette était assistée dans cette tâche par Audrey Crabey, qui a ainsi été formée à la documentation du petit matériel archéologique. 650 objets ont été fichés, et de nouvelles séries hors normes ont été mises au jour, qui feront l'objet de publications spécifiques - notamment une série d'hommes bossus et une autre de singes enceintes et/ou hermaphrodites.

Enfin, rejoignant ses recherches sur le jeu dans le cadre de l'ERC Locus Ludi, M.L. Arnette a pu isoler un important matériel ludique, plateaux sur ostraca (aussi conservés dans le magasin 25), pions et potentiels objets de randomisation (fig. 28). Si la qualité formelle de certains trahit une provenance sans doute funéraire, d'autres, beaucoup plus simples, témoignent des pratiques ludiques des membres de la communauté, qui n'ont jamais fait l'objet d'une étude approfondie. 
Fig. 28. Plateau de jeu de 20 cases sur ostracon inv. DeM_2020_M23_400 (I. Ibrahim Mohamed).

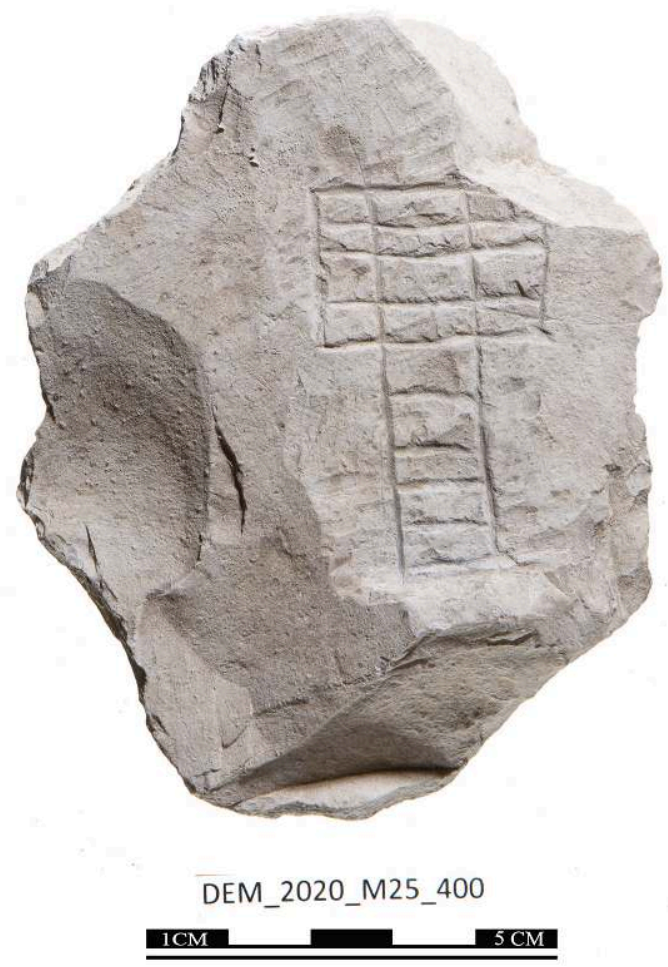

(C) Ifao. 17148_2020_NDMPM_014

\subsection{Anthropologie physique}

69 L'équipe composée d'A. Austin, Mélie Louys, Rosalie David et Keith White avait pour objectif de documenter et de reconditionner les restes humains entreposés dans la tombe de Baki (TT 298). L'équipe a principalement travaillé dans l'antichambre de la tombe où les restes humains ont été trouvés pêle-mêle (fig. 29). Ces restes humains n'ont jamais été étudiés, ils ont donc été photographiés et placés dans des boîtes de conservation pour une étude future (fig. 30). Dans le même temps, tout le matériel culturel trouvé (fragments de cercueil et objets funéraires) a été documenté.

70 Avec l'analyse des restes humains, l'objectif de l'équipe est de répondre aux questions suivantes sur les occupants de la tombe TT 298 :

1. Quelle est la démographie de ceux qui sont enterrés dans la TT 298 ?

2. Ont-ils eu des problèmes de santé ou des traumatismes? 
Fig. 29. Les restes humains mélangés dans la TT 298 au début de la mission 2020 (A. Austin).

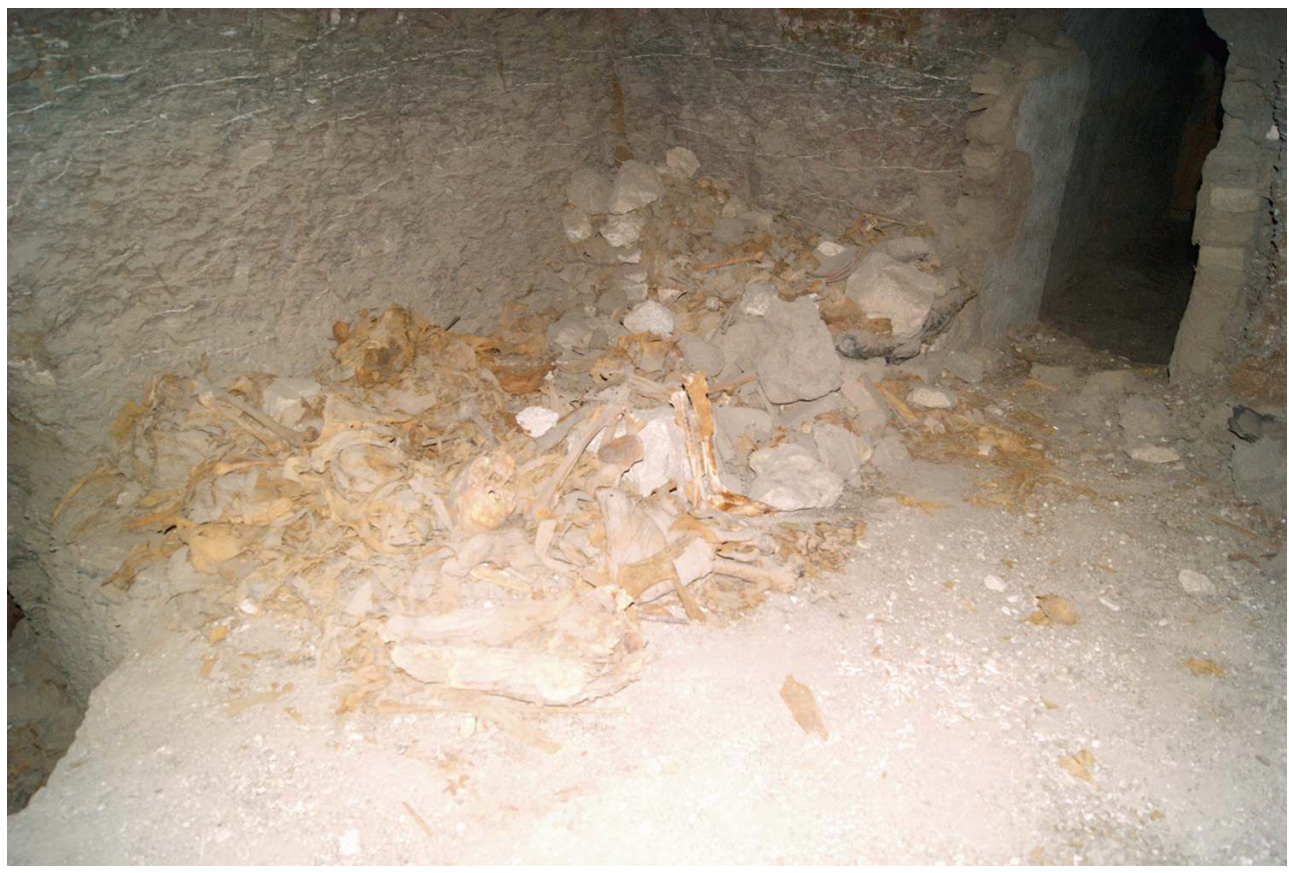

(c) Ifao. 17148_2020_NDMPF_012

Fig. 30. La TT 298 à la fin de la mission 2020 après nettoyage et stockage des restes humains et des artefacts associés (A. Austin).

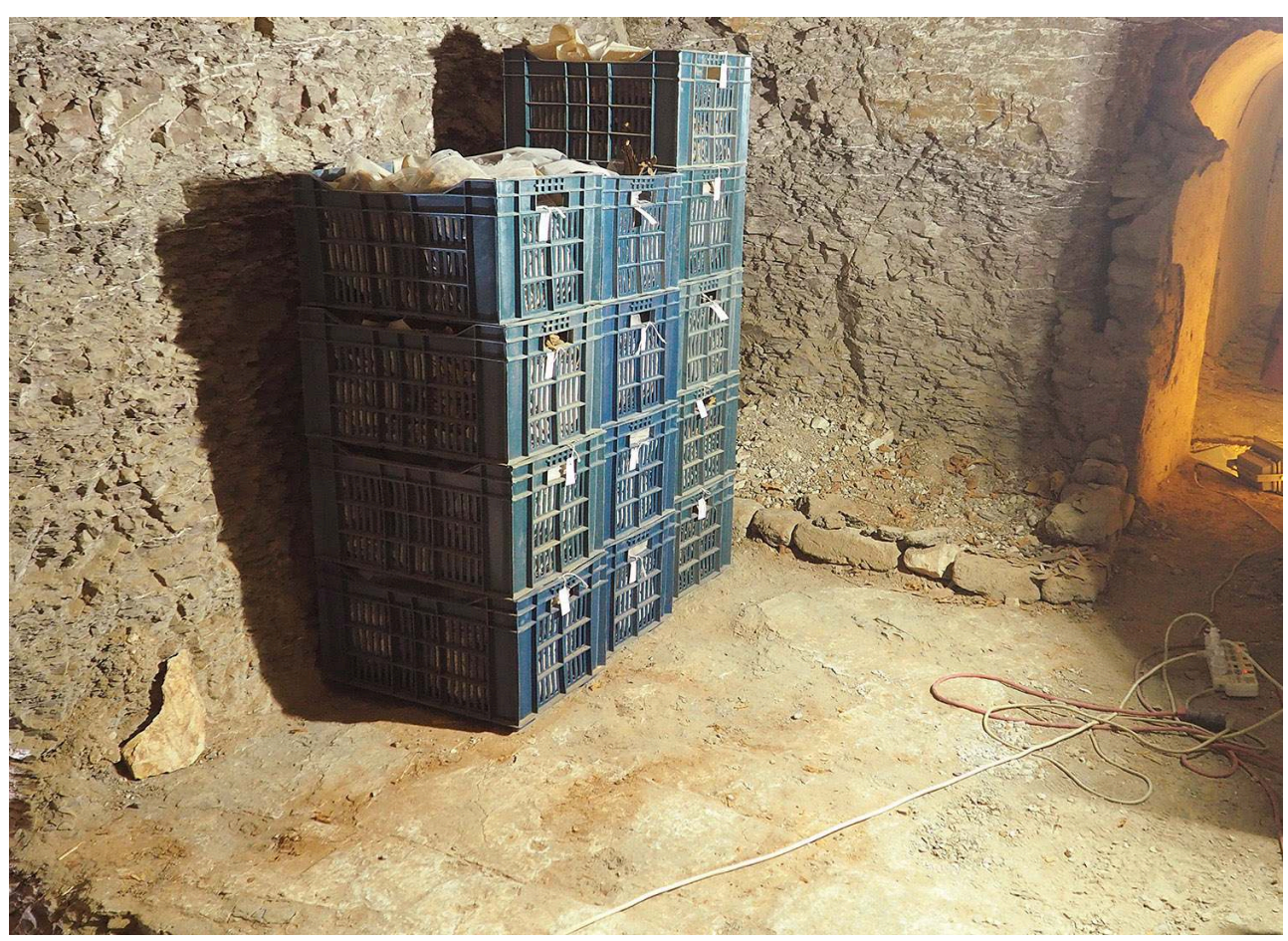

(C) Ifao. 17148_2020_NDMPF_013

71 L'analyse ostéologique a été menée via OsteoSurvey, un ensemble de fichiers XML conçus pour Open Data Kit (ODK) Collect. ODK Collect est un outil open source pour la collecte de données mobiles qui permet aux chercheurs d'effectuer une saisie de 
données personnalisée sur un appareil mobile ou une tablette ${ }^{18}$. Les observations ostéologiques enregistrées à Deir el-Médina sont fondées sur une combinaison de pratiques standardisées en bioarchéologie/anthropologie médico-légale ${ }^{19}$.

L'équipe a analysé 463 éléments squelettiques et fragments momifiés. La distribution des éléments suggère une fréquence plus élevée des restes d'enfants (52/404 ou $11 \%$ des os avec des estimations d'âge) que celle trouvée dans d'autres contextes de tombes à Deir el-Médina. Les jeunes représentés comprenaient tous les groupes d'âge (fig. 31). En comptabilisant les fémurs droits, nous avons actuellement un nombre minimum de 25 individus dans la tombe. Les traumatismes, la formation de nouveaux os périostés, la cribra orbitalia et l'arthrose ont été documentés parmi les restes humains. Alors que les fractures étaient rares (2/42 ou $5 \%$ des fémurs), les exemples que nous avons étaient sévères. Parmi ceux-ci, la fracture du fémur 298.20.193 (fig. 32) est très mal alignée, mais semble complètement guérie. Il s'agissait d'une blessure grave qui aurait complètement cassé la diaphyse fémorale. Parmi les mandibules et maxillaires à dentition observables, 4/18 (22\%) avaient une ou plusieurs hypoplasies. La cribra orbitalia était présente pour 5/19 (26\%) des crânes observables. Ces pourcentages sont plus élevés que ceux du TT 290, mais cela peut être dû à la petite taille de l'échantillon.

Fig. 31. Répartition des os de juvéniles de la TT 298 par catégorie d'âge (A. Austin).

\section{RÉPARTITION DES OS PAR ÂGE DANS LA}

\section{TT298}

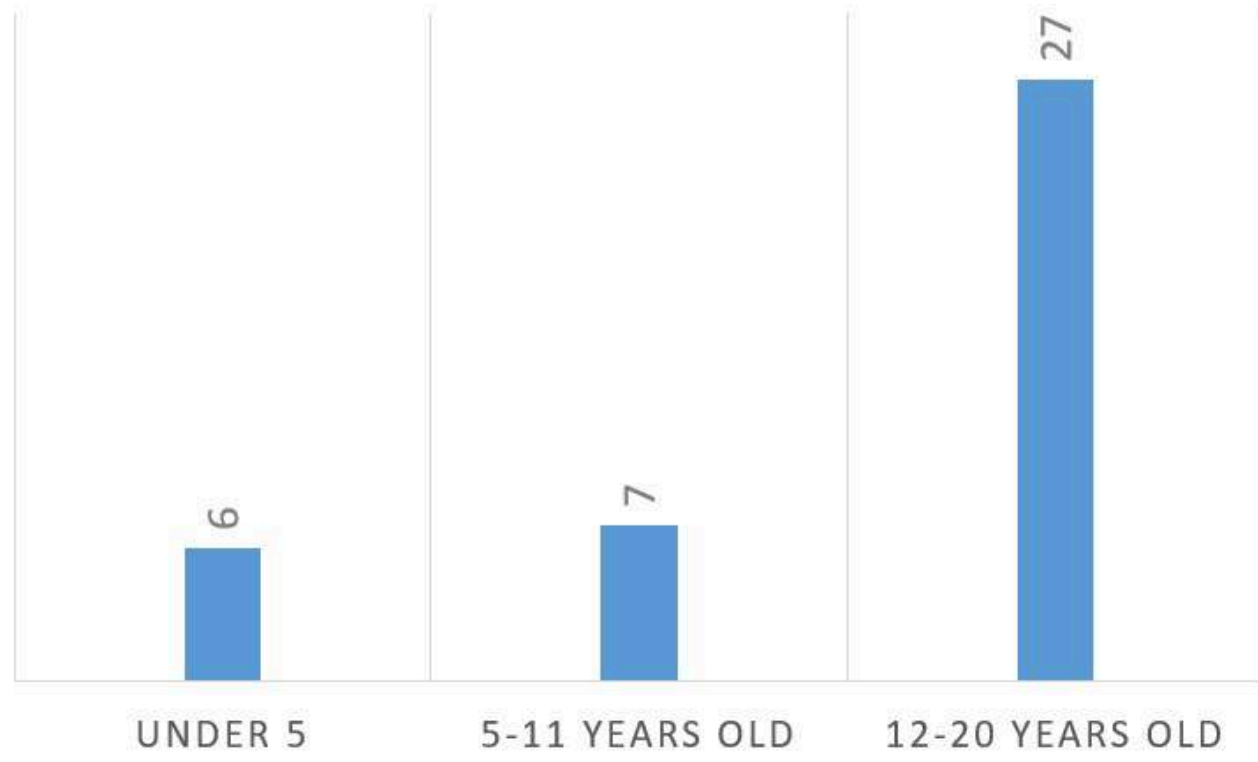

(C) Ifao. 17148_2020_NDMPM_015 
Fig. 32. Une fracture mal alignée du fémur (inv. 298.20.193, A. Austin).

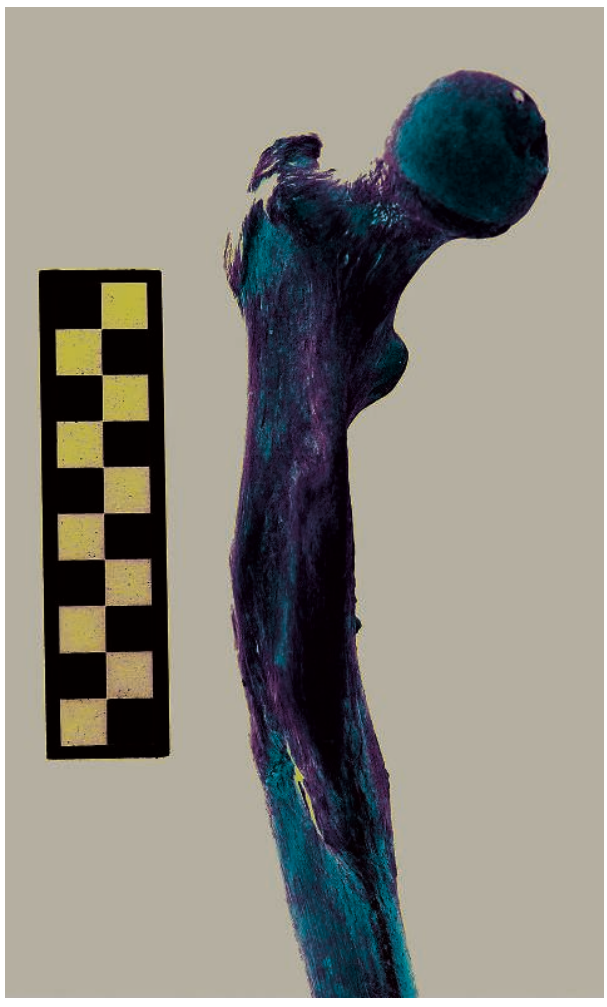

(C) Ifao. 17148_2020_NDMPM_016

73 Nos recherches indiquent que cette tombe contenait au moins 25 individus, mais étant donné la quantité de matériel non étudié, le nombre minimum d'individus est probablement beaucoup plus élevé. Parmi ceux-ci, nous avons des preuves de l'inhumation et de l'inclusion d'enfants; par exemple, les fémurs enveloppés d'un enfant de six mois (inv. 298.20.165 ; fig. 33). Ceci indique que les enfants étaient aussi momifiés et enterrés dans cette tombe. Contrairement aux recherches précédentes sur la TT 290, il semble y avoir plus d'individus décédés à l'adolescence dans cet assemblage. Cela peut suggérer des taux de mortalité différents à Deir el-Médina, selon l'emplacement de la tombe ou la période d'inhumation. 
Fig. 33. Les fémurs enveloppés d'un nourrisson d'environ 6 mois (inv. 298.20.165, A. Austin).

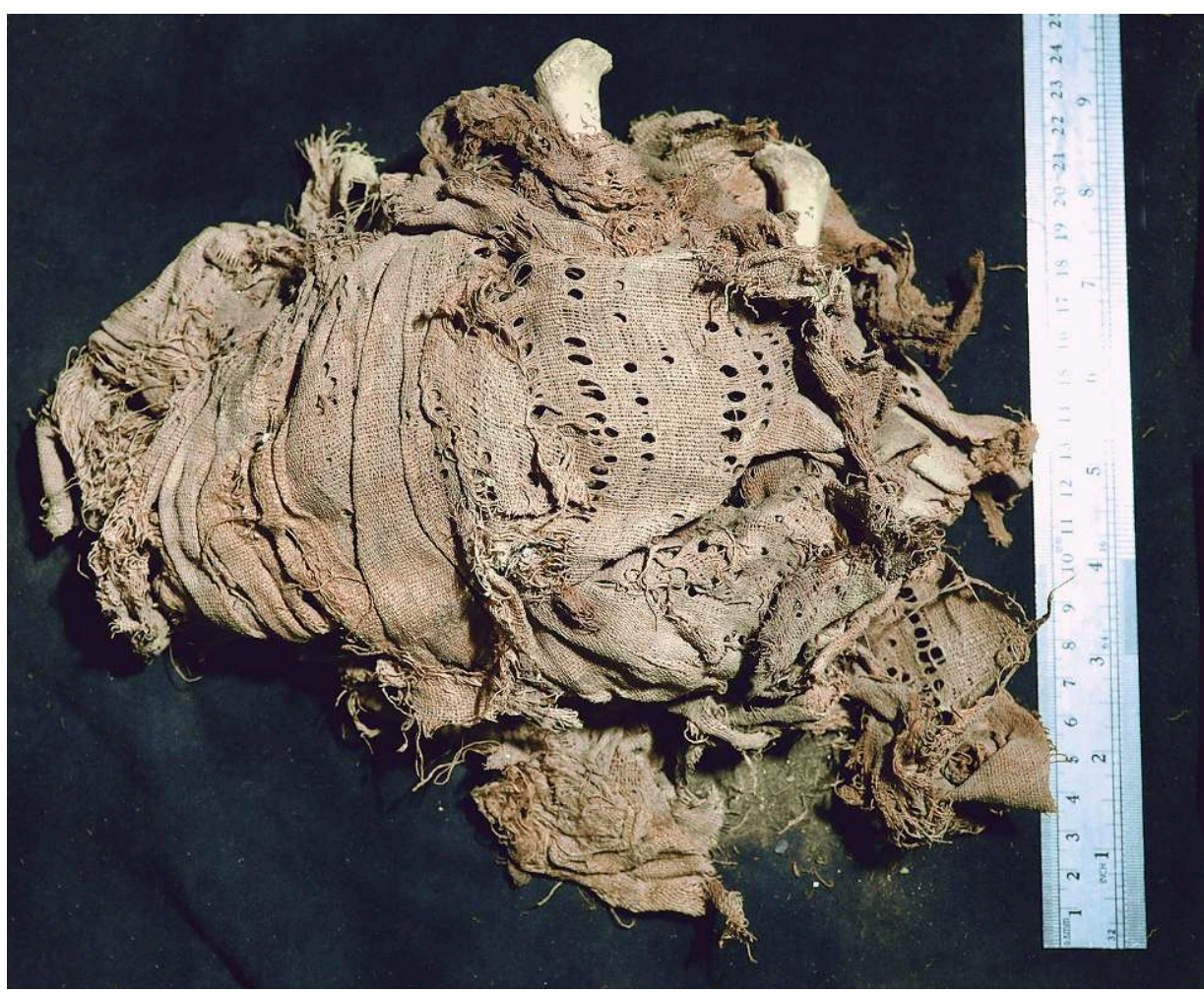

(C) Ifao. 17148_2020_NDMPM_017

74 Les méthodes ostéologiques rendent difficiles les estimations de l'âge des adultes plus âgés, mais parmi les restes découverts jusqu'à présent, nous avons également trouvé des preuves pour des personnes âgées qui auraient probablement plus de 50 ans. Cela confirme les recherches précédentes sur les enterrements familiaux à Deir el-Médina et démontre que ces enterrements familiaux incluent les nourrissons jusqu'aux personnes âgées.

75 Les données préliminaires suggèrent que la santé des personnes enterrées dans la TT 298 était moins bonne que dans la TT $290^{20}$, mais une évaluation complète de la tombe est nécessaire pour déterminer si cela est confirmé. Le désalignement de l'os 298.20.193 suggère que l'individu n'a subi aucune intervention médicale pour réaligner la fracture avant qu'elle ne guérisse. De plus, comme l'os guérissait selon l'angle de la cassure, l'individu aurait eu une démarche altérée et aurait peut-être été définitivement invalidé après la blessure. Bien que ce ne soit qu'un exemple, il apporte des informations importantes sur les maladies et le handicap à Deir el-Médina.

\section{Temple d'Hathor}

\subsection{Deir el-Médina à l'époque gréco-romaine}

76 La richesse archéologique du site de Deir el-Médina est particulièrement reconnue pour le Nouvel Empire, mais toutes les époques y sont représentées, depuis le Moyen Empire jusqu'à l'époque copte. Le projet Deir el-Médina à l'époque gréco-romaine conduit par Sandrine Vuilleumier a pour but de dresser un panorama détaillé de l'occupation des lieux durant les époques grecque et romaine, afin d'analyser le développement et le 
fonctionnement du site durant ces périodes. Ce projet s'articule autour deux axes principaux : d'une part l'analyse du temple ptolémaïque et de ses alentours et d'autre part l'inventaire et l'étude de l'ensemble du matériel gréco-romain provenant de Deir el-Médina. Il aura notamment pour objectif de réfléchir aux raisons qui ont mené à la reconstruction à Deir el-Médina d'un temple à l'époque ptolémaïque, de reconstituer le contexte dans lequel cet édifice a été en activité et d'envisager son rôle et son intégration au sein du paysage cultuel, funéraire et social de la rive ouest de Thèbes.

La reprise des recherches relatives au temple ptolémaïque de Deir el-Médina, dont les inscriptions ont été publiées en 2002, a pour but de réaliser une étude spécifique et complète de cet édifice. Celle-ci comprendra l'étude architecturale des différentes parties du temple, la traduction de ses inscriptions, l'examen approfondi de son programme décoratif en proposant des analyses iconographique, textuelle et religieuse, ainsi que des comparaisons avec d'autres bâtiments. Ces étapes seront complétées par l'élaboration d'une paléographie des inscriptions hiéroglyphiques du temple. Tant pour l'iconographie que pour la paléographie, on s'attachera à étudier le rôle des couleurs qui y sont préservées. Un second pan des recherches sera consacré à l'étude du matériel ptolémaïque et romain découvert à Deir el-Médina dont on dressera un inventaire complet en vue de son étude. Les objets seront documentés et analysés et on s'attachera à situer le plus précisément possible les lieux de leur découverte afin de dresser une carte de l'occupation du site à l'époque gréco-romaine.

Une première mission, qui s'est déroulée du 28 janvier au 15 mars 2020, a permis de commencer la couverture photographique en couleur des décors et des inscriptions du temple. Des clichés ont été pris dans les trois chapelles, le pronaos, la salle hypostyle, le «mammisi » et le temple adossé. Une rapide collation des textes a été réalisée en vue de leur traduction. Ces éléments permettront de poursuivre l'étude du temple en confrontant les textes et les représentations; les recherches documentaires se poursuivent dans ce but. Une première série de photographies de détail des hiéroglyphes a également été réalisée afin de préparer la paléographie hiéroglyphique des inscriptions du temple ptolémaïque.

Des signes particuliers et des variantes intéressantes ont ainsi pu être répertoriés, et l'emploi des couleurs fera l'objet d'une attention particulière. Faute d'accès aux magasins, il n'a malheureusement pas été possible d'entamer l'inventaire du matériel gréco-romain conservé sur le site. On a cependant commencé à réunir l'ensemble des informations relatives à cette documentation, contenue dans les publications et les rapports de fouilles, ainsi que dans les carnets de fouilles d'Ernesto Schiaparelli, de Georg Möller et de B. Bruyère. Il a ainsi été possible de dresser une liste sommaire d'objets à retrouver qui permettra de se mettre en quête du matériel gréco-romain préservé dans les magasins du site et facilitera les travaux des prochaines missions. Par ailleurs, plusieurs objets gréco-romains provenant de Deir el-Médina ont été repérés dans les collections des musées et intégrés à la base de données conçue pour dresser l'inventaire de ce matériel et en faciliter l'étude.

\subsection{Les graffiti et dipinti démotiques de Deir el-Médina}

La mission de quelques jours (22-26 février 2020) conduite par Didier Devauchelle et Ghislaine Widmer avait pour but d'effectuer un dernier pointage des textes démotiques gravés et peints sur les parois et le toit du temple d'Hathor de Deir el-Médina, en vue 
d'une couverture photographique qui devrait avoir lieu en 2021. Le travail fait suite à deux brèves missions effectuées en 2002-2003 et 2006 (voir les rapports d'activité correspondants).

81 Les observations déjà effectuées ont pu être affinées. Les textes incisés (= graffiti) ou peints (= dipinti) sont datables entre la fin de l'époque ptolémaïque et le début de la période romaine et se répartissent dans quatre zones :

1) La façade du temple (6) et la porte extérieure (2) : uniquement des graffiti (fig. 34).

Fig. 34. Graffito incisé sur la façade extérieure du temple : « Le beau nom de Pamontou fils de Pairy » (p3 rn nfr n Pa-Mnt s 3 Pa-iry) (I. Ibrahim Mohamed).

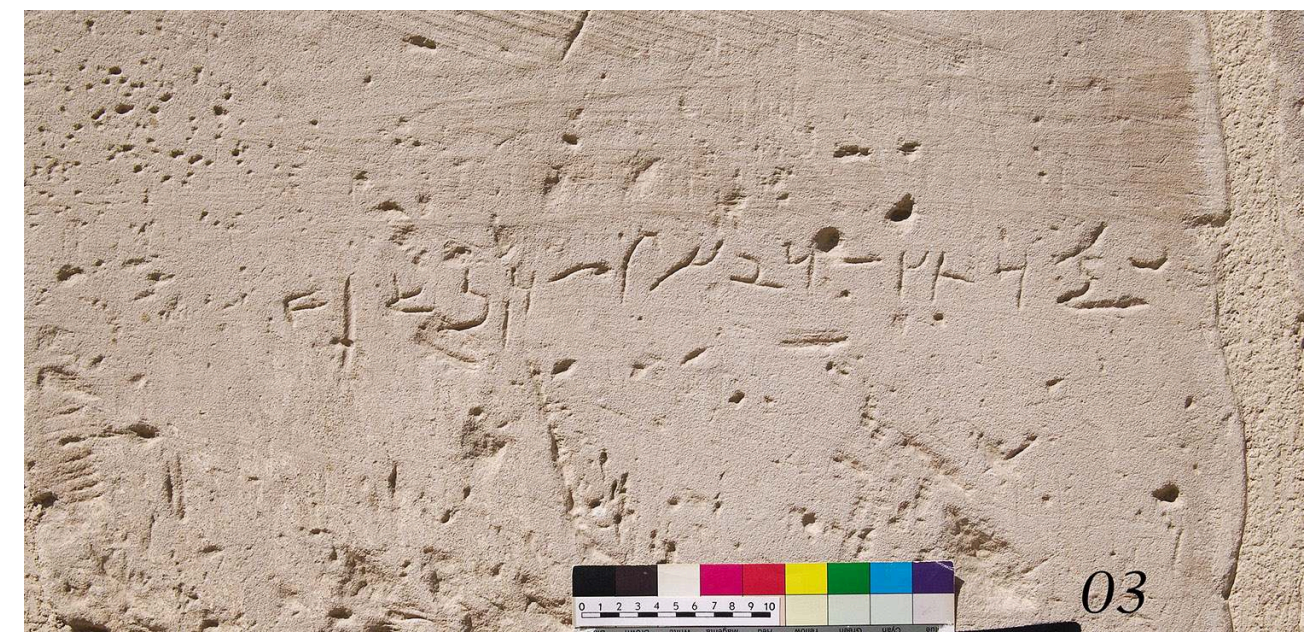

(C) Ifao. NU_2004_01136

2) La salle hypostyle, côté sud: une trentaine, essentiellement des dipinti rouges dont certains sont effacés et difficiles à isoler, car l'enduit de l'époque copte qui les recouvrait est irrégulièrement conservé (fig. 35). 
Fig. 35. Trois croix coptes tracées sur l'enduit qui recouvrait les dipinti démotiques rouges (salle hypostyle, paroi est).

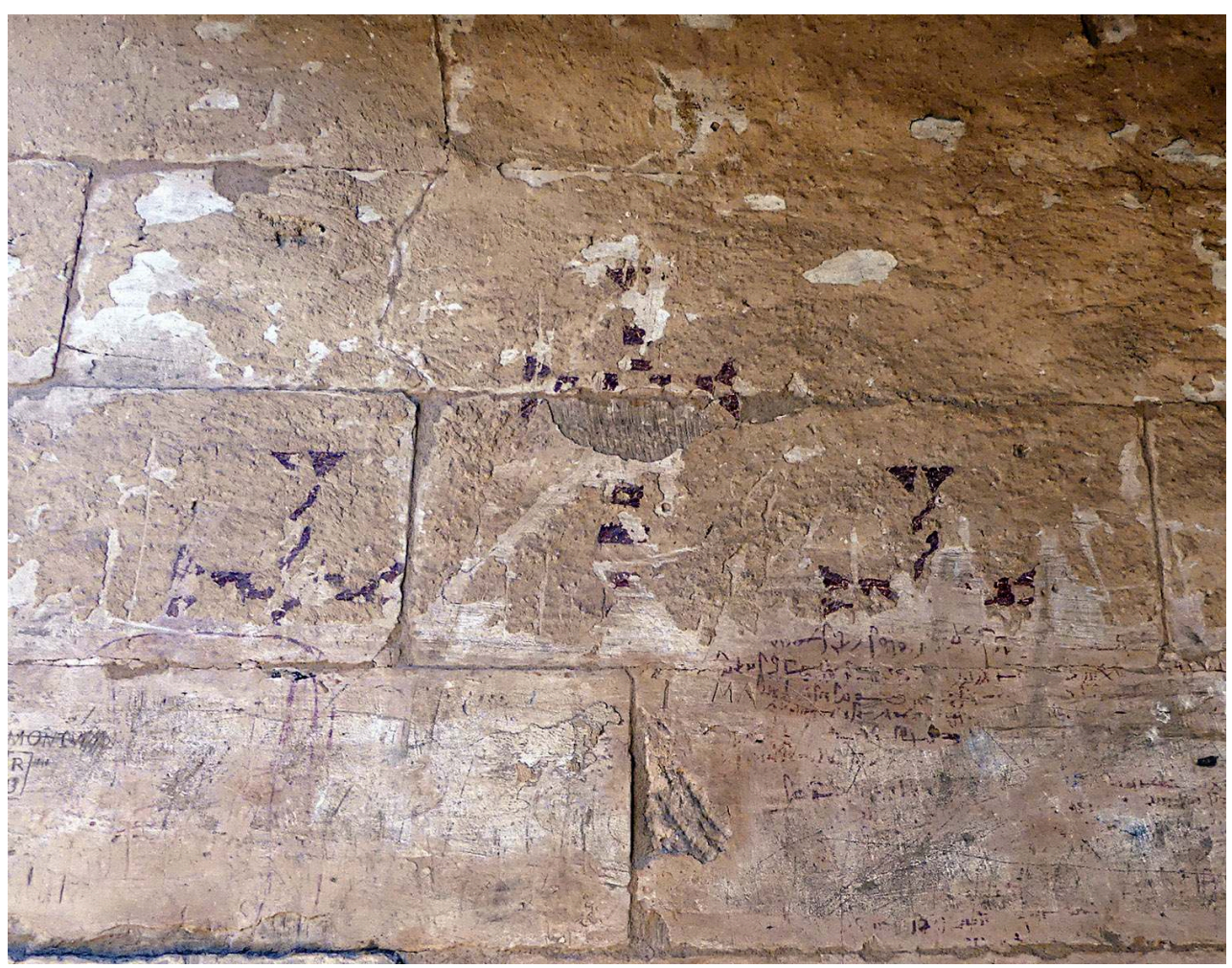

(C) Ifao. 17148_2020_NDMPF_014

3) Les trois chapelles : une dizaine de dipinti à l'encre noire révélés par un nettoyage récent de la surface picturale (fig. 36 ). 
Fig. 36. Dipinto noir à l'intérieur de la chapelle nord, paroi sud, à côté d'une représentation de la déesse Hathor, mentionnée à la ligne 4. L'inscription est datée du mois de juillet de l'an 15 de notre ère, sous le règne de Tibère (I. 5-6) : h. 3.t-sp 1.t (Tybrs (Gysrs ỉbd 3 šmw sw 23(?) (I. Ibrahim Mohamed).

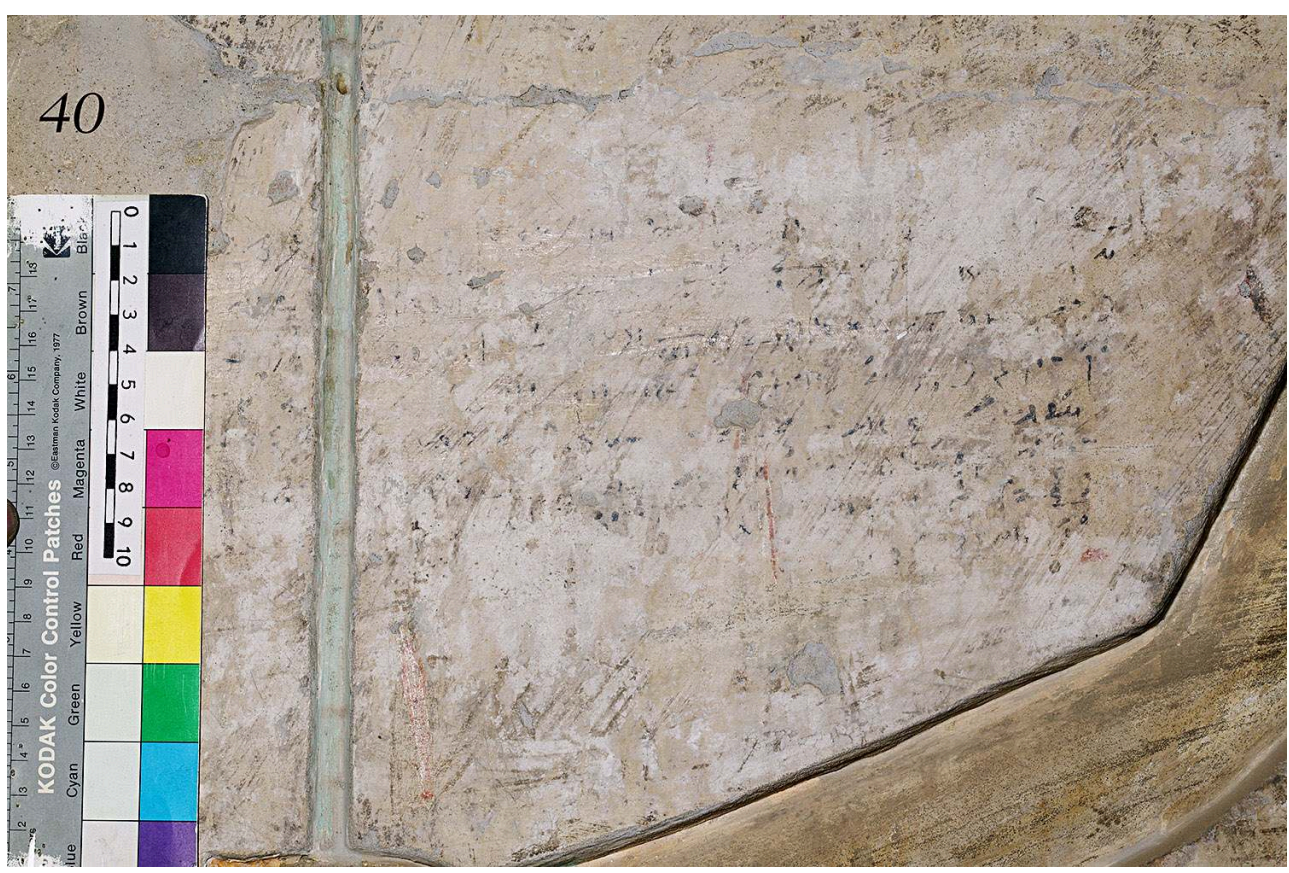

(c) Ifao. NU_2004_001183

4) Le toit : une dizaine de graffiti dont certains sont presque totalement arasés. On note plusieurs empreintes de pieds associées à une inscription démotique, une pratique attestée par ailleurs dans un contexte similaire (fig. 37).

Fig. 37. Contour de pied avec inscription démotique : "Gela fils de Pamontou » (G/3 s3 Pa-Mnt) (I. Ibrahim Mohamed).

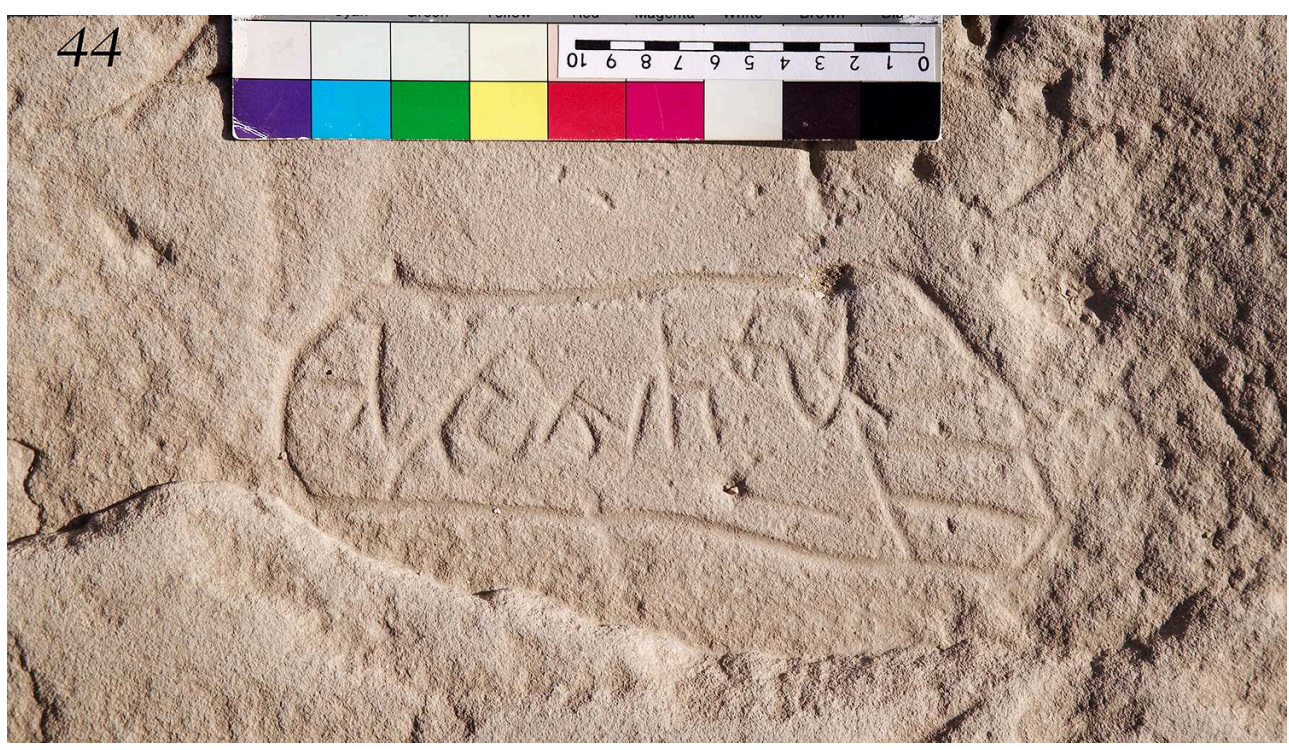

(c) Ifao. NU_2004_01188

82 Le nombre exact d'inscriptions démotiques dans le temple reste difficile à déterminer en raison de l'état de conservation parfois médiocre du support; on peut supposer 
qu'une partie d'entre elles est perdue, notamment les dipinti qui auraient pu être tracés sur la paroi nord de la salle hypostyle où de rares traces d'encre rouge ont été repérées.

Les graffiti, à quelques exceptions près, sont beaucoup plus courts que les dipinti et ne comportent souvent que des anthroponymes, avec ou sans la formule traditionnelle « le beau nom de X demeure ici devant Hathor ». D'autres divinités locales apparaissent, en particulier dans les dipinti rouges, notamment "Semataouy l'enfant». Comme déjà relevé, la présence de ce dieu aux côtés d'Hathor est un des éléments religieux les plus notables, qui contraste avec la place réduite qu'occupe cette divinité enfant dans les inscriptions hiéroglyphiques du temple. On notera encore que quelques dipinti préservent une invitation à " réciter ces écrits » et la menace qu'Hathor « interrompe le temps de vie " ( $\check{s}^{\prime} d$ ' $h$ ' ) de toute personne qui serait tentée de les effacer.

Durant cette mission l'opportunité nous a été donnée d'étudier trois dipinti démotiques de la TT 216, dont deux nouvellement découverts : ils sont de nature funéraire et deux d'entre eux sont précisément datés du règne de Claude (le troisième est également romain).

\subsection{Enquête géoarchéologique}

L'esquisse sommaire de la géologie du site, produite en 2019, a été complétée par Christian Dupuis pour tenir compte des observations de 2020. Bien que très simple, elle est utile pour délimiter les thèmes géoarchéologiques à envisager pour documenter le substrat du site et accompagner les travaux archéologiques en développement. Pour rappel, d'un point de vue strictement géologique, deux ensembles très différents sont à considérer séparément: le substrat tertiaire formé par la succession, Esna Shale (y compris les marnes calcaires de Gourna maintenant individualisées) - calcaire de Thèbes (unité A) basculée et la formation des brèches de Deir el-Médina (quaternaire) qui repose en discordance sur le substrat tertiaire et porte le glacis morphologique du chemin de la Vallée des Rois. Cette année, il a été possible de distinguer deux membres différents CS et CB dans les brèches de Deir el-Médina.

Au cours de cette mission, l'accent a été mis sur :

1. la partie nord du site autour de la TT 216 principalement concernée par le calcaire de Thèbes et son système de diaclases et de fractures. La thématique géoarchéologique générale est de comprendre l'influence des diaclases et autres fractures sur le creusement antique des caveaux, la préservation des peintures et d'accompagner les opérations de restauration de la TT 216 ;

2. la partie sud du site où, entre les TT 214 et 1126, les composantes de la formation des brèches de Deir el-Médina affleurent suffisamment bien pour en établir la stratigraphie, au moins préliminaire. Cette stratigraphie des brèches de Deir el-Médina pourra être appliquée en souterrain dans les tombes de la nécropole de l'ouest. La composante géologique de ces approches contribuant de toute façon à la construction du cadre géologique de l'ensemble du site.

\subsection{Historiographie}

87 La mission a poursuivi son enquête autour de l'histoire des fouilles de Deir el-Médina, et notamment sur l'empreinte des interventions archéologiques sur le site. Julian Posch 
a réalisé des prises de vues au même endroit où elles avaient été prises lors de fouilles anciennes. Notre objectif est de documenter la manière dont les vestiges ont été reconstitués en comparant les structures visibles sur les photographies prises au moment de leurs mises au jour avec celles que l'on peut voir actuellement sur le site.

Fig. 38. Prise de vue depuis la colline de Gournet Mouraï.

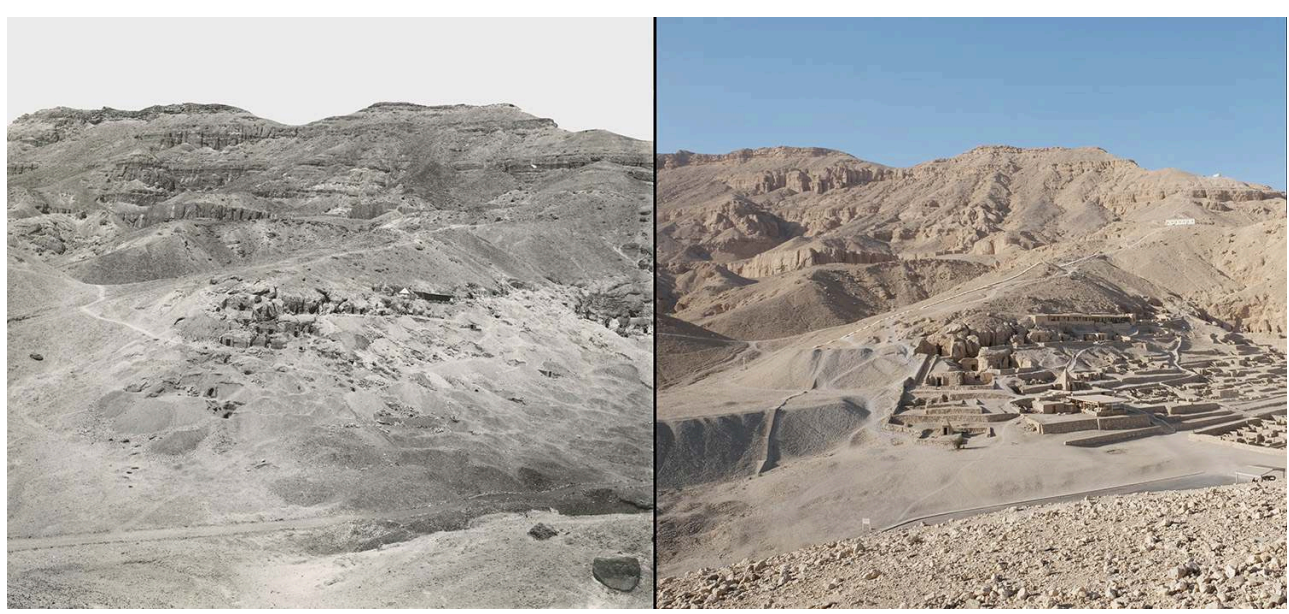

(c) Ifao. 17148_2020_NDMPF_015

Fig. 39. Prise de vue depuis le chemin qui mène à la maison de fouille.
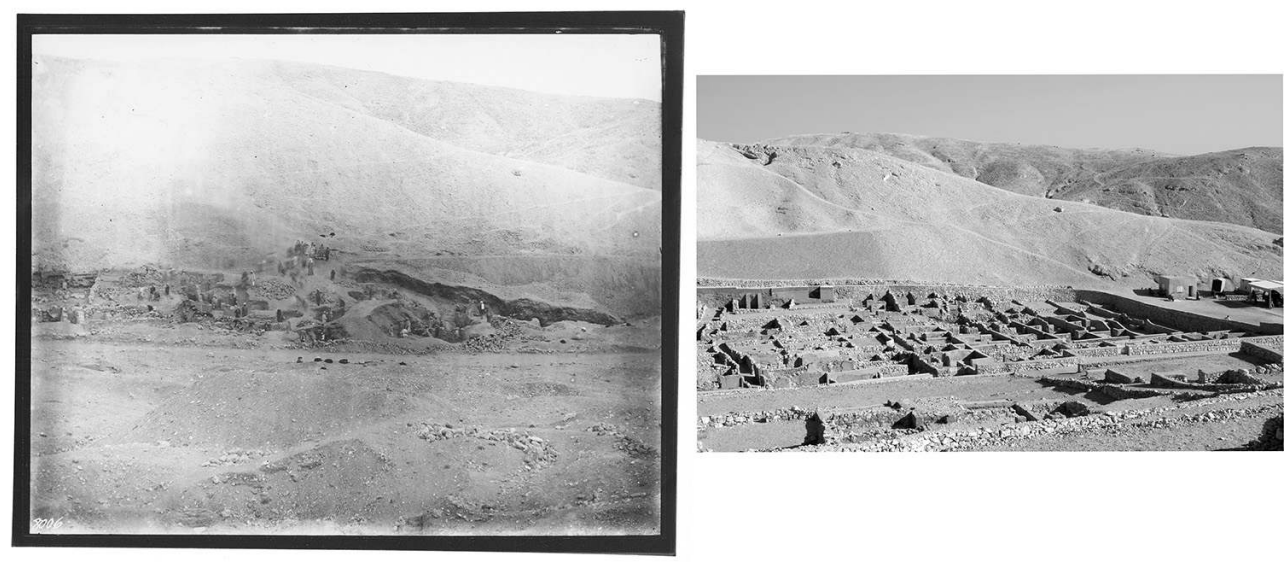

(C) Ifao. 17148_2020_NDMPF_016

\section{Publications des membres de la mission}

- Marie-Lys Arnette, Anne Austin, « Of Ink and Clay: Tattooed Mummified Human Remains and Female Figurines from Deir el-Medina ", soumis au JEA (21 p., in peerreview process).

- Anne Austin, "Injuries, Illness, and Care while Constructing the Royal Tomb ", in Fredrik Hagen, Rune Olsen, Daniel Soliman (éd.), Tomb Construction in New Kingdom Egypt, Cambridge University Press, soumis et accepté.

- Ben J.J. Haring, "The Survival of Pharaonic Ostraca: Coincidence or Meaningful Patterns? ", in Clementina Caputo, Julia Lougovaya (éd.), Using Ostraca in the Ancient 
World: New Discoveries and Methodologies, Materiale Textkulturen 32, Berlin, Boston, De Gruyter, 2020, p. 89-108.

- Ben J.J. Haring, «'Afraid of What?' A Soothing Letter to Pharaoh's Workmen (P. Turin Cat. 2022) ", in Joanne V. Stolk, Guus A.J.C. van Loon (éd.)., Text Editions of (Abnormal) Hieratic, Demotic, Greek, Latin and Coptic: Some People Love their Friends also When They Are Far Away. Festschrift in Honour of Franscisca A.J. Hoogendijk, P.L.Bat. 37, Leiden, Boston 2021, p. 3-12.

- Kyra van der Moezel, «Deliberate Use of Metaphor as Mnemonic Device for Identification in a Non-Linguistic Modality. The Case of Deir el-Medina ", in Camilla Di Biase-Dyson, Markus Egg (éd.), Drawing Attention to Metaphor: Case Studies Across Time Periods, Cultures and Modalities, Figurative Thought and Language 5, Amsterdam, John Benjamins Publishing Company, 2020, p. 93-127.

\section{Conférences}

- Anne Austin, «Recent Evidence for the Practice of Tattooing in Ancient Egypt ", Annual Conference of Society for the Study of Egyptian Antiquities, Toronto, Canada.

- Elizabeth Bettles, "'Serifs' in Painted Hieroglyphs? Observations from the Tomb of Inherkhâouy (TT 359) at Deir el-Medina », Annual Conference of Society for the Study of Egyptian Antiquities, Toronto, Canada.

- Kyra van der Moezel, « Graphic Change in Ancient Egypt: Hieratic Writing of the New Kingdom ", Sprachliche Diversität: Theorien, Methoden, Ressourcen. 42. Jahrestagung der Deutschen Gesellschaft für Sprachwissenschaft (DGfS), 5 mars 2020, université d'Hambourg.

- Sandrine Vuilleumier, "Ornamental and Scriptural Blue. Usage in the Ptolemaic Temple of Deir el-Medina and the Local Funerary Material », colloque international "The Colour Blue in Ancient Egypt and Sudan», 3-4 mai 2020, université de Copenhague.

\section{BIBLIOGRAPHIE}

AUSTIN 2018.

Anne Austin, «Living and Dying at Deir El-Medina: An Osteological Analysis of the TT290 Assemblage ", in Andreas Dorn, Stéphane Polis (éd.), Outside the Box: Selected Papers from the Conference Deir El-Medina and the Theban Necropolis in Contact, Liège, 27-29 October 2014, AegLeod 11, Presses universitaires de Liège, Liège, 2018, p. 27-47.

BRICKLEY, MCKINLEY (éd.) 2004

Megan Brickley, Jacqueline I. McKinley (éd.), Guidelines to the Standards for Recording Human Remains, Institute of Field Archaeologists Paper 7, Southampton 2004.

BRUNETTE et al. 2013

Waylon Brunette, Mitchell Sundt, Nicola Dell, Rohit Chaudhri, Nathan Breit, Gaetano Borriello, «Open Data Kit 2.0: Expanding and Refining Information Services for Developing Regions », in 
Proceedings of the 14th Workshop on Mobile Computing Systems and Applications 10, New York, ACM, 2013.

BRUYÈRE 1928

Bernard Bruyère, Rapport sur les fouilles de Deir el Médineh (1927), FIFAO 5, Le Caire, Ifao, 1928.

BRUYÈRE 1939

Bernard Bruyère, Rapport sur les fouilles de Deir el Médineh (1934-1935). Troisième partie : le village, les décharges publiques, la station de repos du col de la Vallée des Rois, FIFAO 16/3, Le Caire, Ifao, 1939.

BRUYÈRE 1953

Bernard Bruyère, Rapport sur les fouilles de Deir el Médineh (années 1948 à 1951), FIFAO 26, Le Caire, Ifao, 1953.

Buikstra 1994

Jane E. Buikstra, Standards for Data Collection from Human Skeletal Remains: Proceedings of a Seminar at the Field Museum of Natural History, organized by Jonathan Haas, Arkansas Archaeological Survey Research Series 44, Fayetteville, Arkansas Archeological Survey, 1994.

ČERNY 1927

Jaroslav Černy, « Le culte d'Amenophis I chez les ouvriers de la Nécropole thébaine », BIFAO 27, 1927, p. 159-203.

DEMICHELIS 2016

Sara Demichelis, « Ricomporre frammenti. Lavori in corso tra i papiri del Museo Egizio di Torino », in Emanuele M. Ciampini, Sara Demichelis (éd.), Dal Po al Nilo. Studi di filologia ed epigrafia egizia, Memorie della Accademia delle Scienze di Torino. Classe di Scienze Morali, Storiche e Filologiche 40, Turin, 2016, p. 3-44.

DORN 2011

Andreas Dorn, Arbeiterhütten im Tal der Könige. Ein Beitrag zur altägyptischen Sozialgeschichte aufgrund von neuem Quellenmaterial aus der Mitte der 20. Dynastie (ca. 1150 v. Chr.), AegHelv 23, Bâle, Schwabe, 2011.

HARING 2018

Ben J.J. Haring, From Single Sign to Pseudo-Script: An Ancient Egyptian System of Workmen's Identity Marks, CHAN 93, Leyde, Boston, Brill, 2018.

LANGLEY et al. (éd.) 2016

Nathalie R. Langley, Lee M. Jantz, Stephen D. Ousley, Richard L. Jantz, George Milner (éd.), Data Collection Procedures for Forensic Skeletal Material 2.0, Knoxville, University of Tennessee, Lincoln Memorial University, 2016.

MITCHELL, BRICKLEY (éd.) 2017

Piers D. Mitchell, Megan Brickley (éd.), Updated Guidelines to the Standards for Recording Human Remains, Reading, Chartered Institute for Archaeologists, 2017.

SOLIMAN 2016

Daniel M. Soliman, Of Marks and Men: The Functional and Historical Context of the Workmen's Marks of the Royal Theban Necropolis, thèse de doctorat, université de Leyde, 2016.

SOLIMAN 2018

Daniel M. Soliman, « Ostraca with Identity Marks and the Organisation of the Royal Necropolis Workmen of the 18th Dynasty », BIFAO 118, 2018, p. 465-524.

STECKEL et al. (éd.) 2019

Richard H. Steckel, Clark S. Larsen, Charlotte A. Roberts, Joerg Baten (éd.), The Backbone of Europe: 
Health, Diet, Work and Violence over Two Millennia, Cambridge Studies in Biological and Evolutionary Anthropology 80, Cambridge, Cambridge University Press 2019.

VAN DER MOEZEL 2016

Kyra V.J. van der Moezel, of Marks and Meaning: A Palaeographic, Semiotic-Cognitive, and Comparative Analysis of the Identity Marks from Deir el-Medina, thèse de doctorat, université de Leyde, 2016.

\section{NOTES}

1. ČERNY 1927, pl. IV, fig. 1-2.

2. Cat.1827/1 Drovetti Collection, 1824, cf. DEMICHELIS 2016, p. 10-27.

3. The fragments were found by H. Gauthier and J. Lecomte Dunouy in the TT 298 during the French excavations of 1917, Ifao Archive B. Bruyère MS_2004_00148_032, "un livre des morts en débris", see BRUYÈRE 1928, p. 92.

4. BRUYÈRE 1928, p. 89, fig. 60.

5. BRUYÈRE 1928, p. 89, fig. 60.

6. BRUYÈRE 1928, p. 89.

7. Ifao Archive J.J. Clère MS_2018_04266.

8. The human remains are cleared and studied by Anne Austin assisted by Mélie Louys.

9. BRUYÈRE 1928, p. 87, fig. 59.

10. Around 50 ostraca were restored and cleaned during this season. Most of them are covered by a thin layer of dirt and salt and sometimes the patterns underneath are not recognizable.

11. As agreed between the authors and the Ifao; contract of authorization d.d. $28 / 3 / 2018$.

12. "Symbolizing Identity", carried out at Leiden University from 2011 to 2015, and funded by the Netherlands Organisation for Scientific Research (NWO). Main publications: HARING 2018; VAN DER MOEZEL 2016; SOLIMAN 2016.

13. E.g. BRUYÈRE 1953, pl. XVIII; SOLIMAN 2018.

14. These two periods can often be distinguished by their repertoires; see HARING 2018 , pp. 158-206; VAN DER MOEZEL 2016, pp. 5-39.

15. See e.g. DORN 2011, pl. 472-477.

16. At least one of which (marked with a lion figure) has been published: BRUYÈrE 1953, p. 49-50, no. 47; possibly also another one (with the "scribe" hieroglyph): BRUYÈrE 1939, p. 233 and 302 (bottom).

17. Already published in BRUYÈRE 1953, p. 65, fig. 15, p. 83 (bottom). Probably not an identity mark, but a hieroglyphic inscription reading ' $h$ ' $n f r$ "good lifetime".

18. BRUNETTE et al. (éd.) 2013.

19. BUIKSTRA 1994; BRICKLEY, MCKINLEY (éd.) 2004; LANGLEY et al. (éd.) 2016; MITCHELL, BRICKLEY 2017; STECKEL et al. (éd.) 2019.

20. AUSTIN 2018. 


\section{INDEX}

\section{Thèmes : IFAO}

nature https://ark.frantiq.fr/ark:/26678/pcrtwRi2ji9ZSA

Année de l'opération : 2020

lieux https://ark.frantiq.fr/ark:/26678/pcrtkJ3z2ScNP6

sujets https://ark.frantiq.fr/ark:/26678/pcrtOjL41tGiRu, https://ark.frantiq.fr/ark:/26678/

crt6LUYlEWA5e, https://ark.frantiq.fr/ark:/26678/pcrtwRi2ji9ZSA, https://ark.frantiq.fr/ark:/

26678/pcrtRXhdi4O5ST, https://ark.frantiq.fr/ark:/26678/pcrtMr3tb79bV8, https://

ark.frantiq.fr/ark:/26678/pcrtpVNfYQXRzH

\section{AUTEURS}

\section{CÉDRIC LARCHER}

Égyptologue, Ifao

\section{JULIAN POSCH}

Égyptologue, Universität Wien

DOMINIQUE LEFEVRE

Égyptologue, université de Genève

\section{MANON LEFEVRE}

Restauratrice-conservatrice, indépendante

\section{MARINE YOYOTTE}

Égyptologue, Ifao

\section{ELISA FIORE MAROCHETTI}

Égyptologue, Soprintendenza Archeologia Belle Arti e Paesaggio di Torino

GERSANDE ESCHENBRENNER DIEMER

Égyptologue, Universidad de Jaén

ANNA GIULIA DE MARCO

Égyptologue, Università di Pisa

\section{LISA SARTINI}

Égyptologue, Université de Pise

\section{MARGARET SERPICO}

Égyptologue, University College de Londres

BEN J.J. HARING

Égyptologue, Universiteit Leiden 


\section{KYRA VAN DER MOEZEL}

Égyptologue, Johannes Gutenberg-Universität Mainz

MARIE-LYS ARNETTE

Égyptologue, Universität Freiburg

CÉDRIC GOBEIL

Égyptologue, Museo Egizio, Turin

\section{ANNE AUSTIN}

Anthropologue, University of Missouri-St. Louis

SANDRINE VUILLEUMIER

Égyptologue, université de Lausanne

DIDIER DEVAUCHELLE

Égyptologue, université de Lille

\section{GHISLAINE WIDMER}

Égyptologue, université de Lille

CHRISTIAN DUPUIS

Géologue, université de Mons 